\title{
Germanium isotopic systematics in Ge-rich coal from the Lincang Ge deposit, Yunnan, Southwestern China
}

\author{
Hua-Wen $\mathrm{Qi}^{\mathbf{a}}{ }^{*}$, Olivier Rouxel ${ }^{\mathbf{b}}$, Rui-Zhong $\mathrm{Hu}^{\mathbf{a}}$, Xian-Wu Bi ${ }^{\mathbf{a}}$ and Han-Jie Wen ${ }^{\mathbf{a}}$ \\ a State Key Laboratory of Ore Deposit Geochemistry, Institute of Geochemistry, Chinese Academy of Sciences, \\ Guiyang 550002, China \\ ${ }^{\mathrm{b}}$ Institut Universitaire Européen de la Mer (IUEM), Université Européenne de Bretagne (UEB), IFREMER Dept. \\ Géosciences Marines, Plouzané 29280, France \\ *: Corresponding author : Hua-Wan Qi, email address : qihuawen@vip.gyig.ac.cn
}

\begin{abstract}
:
Organic matter plays an important role in the transport and precipitation of germanium (Ge) in coalhosted Ge deposits. In this paper, Ge isotopes of coal samples and their combustion products were analyzed in order to investigate the potential use of $\mathrm{Ge}$ isotopes as tracers of Ge sources and enrichment mechanisms in coal. Germanium isotopic composition of various samples (mainly Ge-rich lignite) from the Lincang Ge deposit, Yunnan, Southwest China was analyzed using a continuous flow hydride generation system coupled to a Multi Collector Inductively Coupled Plasma Mass Spectrometer (MC-ICP-MS) and the standard-sample bracketing approach. Variations of ${ }^{74} \mathrm{Ge} /{ }^{70} \mathrm{Ge}$ ratios are expressed as $\delta^{74} \mathrm{Ge}$ values relative to NIST SRM $3120 \mathrm{a} \mathrm{Ge}$ standard solution. Ge-rich lignite samples show large $\mathrm{Ge}$ isotopic fractionation $\left(\delta^{74} \mathrm{Ge}\right.$ values range from $-2.59 \%$ to $4.72 \%$ ), and their $\delta^{74} \mathrm{Ge}$ values negatively correlate with $\mathrm{Ge}$ concentrations. Lignite samples with low $\mathrm{Ge}$ concentrations $(<500 \mathrm{ppm})$ tend to show positive $\delta^{74} \mathrm{Ge}$ values, while $\delta^{74} \mathrm{Ge}$ values of lignite samples with high Ge concentrations (> $1000 \mathrm{ppm}$ ) are close to zero or negative. Along stratigraphic sections, $\mathrm{Ge}$ is mainly concentrated in the top or the bottom of the coal seam, such that high values of $\delta^{74} \mathrm{Ge}$ are usually found in the middle part of the coal seam. Interlayered hydrothermal chert and limestone samples in Ge-rich coal seams also show moderate fractionation $\left(\delta^{74} \mathrm{Ge}\right.$ values range from $-0.14 \%$ to $2.89 \%$ and from $0.55 \%$ to $1.87 \%$, respectively). The overall variations of $\delta^{74} \mathrm{Ge}$ values of Ge-rich lignite and organic-rich chert samples can be well described by a Rayleigh fractionation model, indicating that preferential enrichment of light $\mathrm{Ge}$ isotopes in coal in an open system might be the main factor controlling $\mathrm{Ge}$ fractionation in Ge-rich lignite. The germanium isotopic composition of hydrothermal chert (and possibly limestone) might also record the competitive fractionation produced by precipitation of quartz and sorption of coal. Elevated Ge concentrations and/or $\delta^{74} \mathrm{Ge}$ values of some chert, limestone, sandstone, and claystone samples may be attributed to the mixing with Ge-rich organic matter. Furthermore, similar to the fractionation of $\mathrm{Zn}, \mathrm{Cd}$ and $\mathrm{Hg}$ isotopes observed between refinery dust or gas and slag, high temperature coal combustion also fractionates Ge isotopes, with the $\mathrm{Ge}$ isotopic compositions of soot being distinctly lighter (up to 2.25 per mil) than those of cinder. The distinct enrichment of potential hazardous elements (i.e., $\mathrm{Pb}, \mathrm{Cd}$, and $\mathrm{As}$ ) and $\mathrm{Ge}$ in soot after coal combustion, as well as the common enrichment of $\mathrm{Ge}$ in sulfide minerals (e.g. sphalerite), highlights the possibility of using $\mathrm{Ge}$ isotopes as useful tracers of sources of heavy metal pollution caused by high temperature industrial processes (coal combustion and $\mathrm{Pb}-\mathrm{Zn}$ refining) in the environment.
\end{abstract}




\section{Research Highlights}

Ge-rich coal samples show large Ge isotopic fractionation. Rayleigh fractionation and mixing control the overall variations. High temperature coal combustion fractionates $\mathrm{Ge}$ isotopes. $\downarrow \mathrm{Ge}$ isotopes can be used as tracers in terms of pollution studies.

Keywords : Germanium; Coal; Stable isotope fractionation; Water-rock interaction; Geochemical tracer

\section{Introduction}

Germanium (Ge) is a trace component in the Earth's crust and natural waters (Bernstein, 1985; Taylor and McLennan, 1985). Germanium substitutes for Si in silicate mineral lattices and is widely dispersed in the crust. Depending on its geochemical environment, Ge shows either siderophile, chalcophile, and organophile behavior, and is consequently enriched in (1) iron meteorites and iron oxides, (2) zinc-rich and copper-rich sulfide ore deposits, and (3) some coal deposits (Bernstein, 1985; Pokrovski and Schott, 1998a; Höll et al., 2007; Qi et al., 2007; Seredin and Finkelman, 2008). In rivers that are distant from industrial regions and sources of coal combustion, the $\mathrm{Ge} / \mathrm{Si}$ atomic ratio is about $0.6 \times 10-6$. Both $\mathrm{Ge}$ concentration and Ge/Si ratios are increased in most hydrothermal waters (Arnórsson, 1984; Mortlock and Froelich, 1986; Mortlock et al., 1993; Pokrovski and Schott, 1998a, 1998b; Evans and Derry, 2002). The unique nature of Ge makes Ge isotopes potentially useful tracers of rock weathering processes, coupled $\mathrm{Ge}$ and $\mathrm{Si}$ geochemical cycling, and the origin of hydrothermal sulfide deposits and Ge-rich deposits in coal mines.

Over the past few years, new advances in Ge isotope systematics have been made regarding (1) the measurement of Ge isotopic compositions of geological and extraterrestrial materials, such as igneous rocks, marine sediments, seafloor hydrothermal fluids, hydrothermal Fe-oxyhydroxides, terrestrial high-temperature geothermal fluids, sphalerite, and iron meteorites (Rouxel et al., 2006; Siebert et al., 2006; Luais, 2007); and (2) theoretical prediction of germanium isotope fractionation ( $\mathrm{Li}$ et al., 2009; $\mathrm{Li}$ and $\mathrm{Liu}, 2010$ ). These preliminary studies have revealed striking $\mathrm{Ge}$ isotopic fractionation (up to 4 per mil for 
${ }^{74} \mathrm{Ge} /{ }^{70} \mathrm{Ge}$ ratios) and provided the foundation for using $\mathrm{Ge}$ isotopes as new geochemical tracers.

As one of the most important Ge-bearing deposits (Höll et al., 2007), coal-hosted Ge deposits represent an unusual reserve of $>1000$ tons with Ge concentrations up to $3000 \mathrm{ppm}$, mainly distributed in Russian Far East (Seredin and Danilcheva, 2001; Seredin and Finkelman, 2008), and Western Yunnan and Inner Mongolia in China (Zhang et al., 1987; Zhuang et al., 1998a,1998b; Qi et al., 2004, 2007a, 2007b; Zhuang et al., 2006; Du et al., 2009; Hu et al., 2009). Since Ge has the highest organic affinities of all elements in coal (Valkovic, 1983), coal-hosted Ge deposits have been regarded as the best example of ore deposits where the organic matter played an important role in their formation (Seredin and Danilcheva, 2001). However, despite its importance, there are still active debates regarding the sources of Ge and the importance of hydrothermal enrichment during coal formation. In this study, we report a comprehensive study of Ge isotopic composition of Ge-rich lignite samples from the Lincang Ge Deposit, Yunnan, Southwest China, which in turn provides important constraints on the mechanisms of Ge isotopic fractionation during water (hydrothermal solution) and rock (coal) interaction in organic-rich geological environments. We also investigated potential Ge isotope fractionation during coal combustion in order to explore the possibility of using Ge isotopes as robust tracers of anthropogenic sources of Ge (i.e. from fossil fuel burning) in the environment.

\section{Geological setting and sample collection}

The Lincang Germanium Deposit (LGD), including the Dazhai and Zhongzhai ore blocks, is located in the Bangmai Basin of Lincang County, Yunnan Province, Southwest China (Fig. 1). Hu et al. (2009) described the regional geological background and the geological characteristics of this deposit in detail. The Bangmai Basin, with an area of 16.4 $\mathrm{km}^{2}$, is a $10-\mathrm{km}$ long and 4.5-km wide half graben, controlled by NW and EW-trending faults and is filled by the Miocene Bangmai Formation with a maximum thickness of $1142 \mathrm{~m}$. The lower part of the Miocene Bangmai Formation is mainly composed of diluvial and alluvial granitic clastic rocks, overlain by an upper sequence of sandstones, siltstones, coal seams and diatomites. The upper sequence is further divided into seven units $\left(\mathrm{N}_{1 \mathrm{~b}}{ }^{2-8}\right)$, three of which are 
coal-bearing $\left(\mathrm{N}_{1 \mathrm{~b}}{ }^{2}, \mathrm{~N}_{1 \mathrm{~b}}{ }^{4}\right.$ and $\left.\mathrm{N}_{1 \mathrm{~b}}{ }^{6}\right)$. The coal seams in these units mainly consist of low maturity lignite and a few bituminous coals. All these near-horizontal sequences, bearing fewer and thinner coal seams, are found in the east limb, while only a few sequences with steeply dipping (up to $75^{\circ}$ ) and thicker coal seams are preserved in the western limb. The Bangmai Formation was deposited onto the Middle Triassic Lincang granitic batholith, which is lithologically composed of biotite- and two-mica granites.

The proven Ge reserve of the LGD is more than 1000 tons. Prospecting data show that the concentrations of Ge in the coal seams of the LGD change both vertically and laterally. Germanium mineralization occurs in the coal seams of the basal coal-bearing unit $\left(\mathrm{N}_{1 b}{ }^{2}\right)$ of the Bangmai Formation (Fig.2). The Ge-mineralized coal seam is interlayered with cherts and siliceous limestones in Zhongzhai, while the other coal seams in the upper two coal-bearing units $\left(\mathrm{N}_{1 \mathrm{~b}}{ }^{4}\right.$ and $\left.\mathrm{N}_{1 \mathrm{~b}}{ }^{6}\right)$ are not interbedded with cherts and siliceous limestones, and are not enriched in Ge. The major and trace element composition, as well as O- and C-isotopic compositions of these cherts and siliceous limestones are similar to those of hydrothermal sediments, indicating formation by hydrothermal sedimentation (Qi et al., 2004; Hu et al., 2009). The main Ge ore bodies are mainly distributed in the west limb of the Bangmai Basin (Fig.2). The equant or elongated orebodies are usually located at fault intersections (Fig.1). The mineralized area in Dazhai is $600 \mathrm{~m}$ long and $400 \mathrm{~m}$ wide, with an area of $0.25 \mathrm{~km}^{2}$. The stratiform or lentiform orebodies, with an average thickness of $4 \mathrm{~m}$ (up to $14.3 \mathrm{~m}$ ), measure $470 \mathrm{~m} \times 400-800 \mathrm{~m}$ in area ( $\mathrm{Li}, 2000)$. Germanium concentrations of coal samples from the mineralized coal seams range from a few tens of ppm to about $2500 \mathrm{ppm}$, with an average of 850 ppm, and Ge appears to be concentrated at the top and the bottom of coal seams, and where coal seams are in contact with cherts or siliceous limestones (Qi et al., 2004; Hu et al., 2009).

The Ge-rich lignite samples are mainly half-bright and half-dull coal with massive structures, which have high huminite (60\%-80\%, mainly corpohuminite), and low semifusite group ( $2 \%$ to $10 \%$, mainly fusovitrite), stable group ( $2 \%$ to $3 \%$, including cutinitem, resinite, small sporinite, alginite and funginite), and mineral component (2\% to 10\%) contents. Ge-free lignites are lithologically similar to Ge-rich lignites, but with lower huminite contents (usually less than 70\%) and banded or massive structures (Han et al., 1994; Zhuang et al., 1998a). The 
results of total elemental analysis of selected raw coal samples with various Ge concentrations from the LGD indicate that the major elemental compositions of Ge-rich lignite samples from the first coal-bearing unit $\left(\mathrm{N}_{1 \mathrm{~b}}{ }^{2}\right)$ are similar to those of Ge-free lignite samples from the second coal-bearing unit $\left(\mathrm{N}_{1 \mathrm{~b}}{ }^{4}\right)$, while Ge-free lignite samples tend to show lower carbon, and higher sulfur and oxygen contents, when compared to those contents of Ge-rich lignite samples (Table 1).

Minerals identified by XRD semiquantitative analysis of Ge-rich lignite samples from this deposit consist mainly of quartz, kaolinite, pyrite, and minor potassic feldspar, illite, calcite, gypsum and barite, while the mineral phases of Ge-free lignite samples consist mainly of pyrite and quartz (Table 2). No discrete Ge minerals have been observed in the deposit. Results of EPMA, TEM-EDX, sequential extraction, and floating experiments (heavy media separation) of coal samples collected from the same coal-bearing unit of the Dazhai ore block show that Ge occurs predominantly (up to 80\%) in huminites (low-reflectance humic materials in lignite) (Zhang et al., 1987; Zhuang et al., 1998b; Hu et al., 2009). Hence, Ge in mineralized coal seams from the LGD is mainly associated with organic matter.

Based on the geological and geochemical characteristics of the LGD and the fact that the solubility of Ge and Si positively increases with temperature (Pokrovski and Schott, 1998a, 1998b), Qi et al. (2004) and Hu et al. (2009) proposed that circulating hydrothermal fluids leached abundant Ge and other elements from Ge-rich granites in the basement. Such hydrothermal fluids were then discharged into the basin, mainly along fault intersections, to form stratiform cherts and siliceous limestones by depositing Si and Ca and forming Ge-rich coal via interaction between Ge in the fluids and organic matter in the coal seams during diagenesis.

38 samples of Ge-rich coal were collected from the recent strip-mine benches of the coal seams (main ore bodies) in the basal coal-bearing unit $\left(\mathrm{N}_{1 \mathrm{~b}}{ }^{2}\right)$, at different portions (the top, middle and bottom) of the coal seams at Dazhai (DZ series samples) and at Zhongzhai (ZZ series samples), respectively. The sampling channels (grooves on the surface of coal seam) were generally 0.15 -m wide $\times 0.20$-m long $\times 0.10$-m deep. Furthermore, 5 sandstone samples from the roof and partings of Ge ore-bodies, 10 hydrothermal chert samples and 5 hydrothermal limestone samples interlayered with Ge-bearing coal seams in the basal 
coal-bearing unit $\left(\mathrm{N}_{1 \mathrm{~b}}{ }^{2}\right)$, and 5 granite samples from the outlying Bangmai Basin were also collected and analyzed. In order to investigate possible Ge isotope fractionation during coal combustion, we analyzed 2 soot samples (which were directly collected from the stockroom of the power plant at Zhongzhai as the raw product from Ge-rich coal combustion), 2 cinder samples (solid waste of combustion of Ge-rich coal, collected from the dump of power plant), and various ashes of Ge-rich lignite prepared after ashing at $600^{\circ} \mathrm{C}$ for $24 \mathrm{~h}$ in a muffle furnace.

\section{Analytical techniques}

\subsection{Sample dissolution and chemical purification}

Less than $100 \mathrm{mg}$ of sample was accurately weighed into PTFE digestion vessels. Samples were first reacted with $10 \mathrm{ml}$ of concentrated $\mathrm{HNO}_{3}$ at $120{ }^{\circ} \mathrm{C}$ for more than $48 \mathrm{~h}$ and taken to dryness on a hot plate at $120^{\circ} \mathrm{C}$. If black organic $\mathrm{C}$ residue remained, an additional $15 \mathrm{ml}$ of concentrated $\mathrm{HNO}_{3}$ were used. Final digestion of the dry residue obtained after $\mathrm{HNO}_{3}$ dissolution was performed using $1 \mathrm{ml}$ of concentrated $\mathrm{HF}$ and $5 \mathrm{ml}$ of milli-Q water. The solution was heated for more than $24 \mathrm{~h}$ in the sealed PTFE containers on a hot plate at a temperature of $120{ }^{\circ} \mathrm{C}$ and solutions were shaken periodically. The solution along with insoluble precipitates were transferred into a polypropylene centrifuge tube and diluted with milli-Q water to obtain a final solution of $\sim 1 \mathrm{~N}$ HF. The supernatant containing Ge and other soluble fluoride complexes was then loaded on an anion-exchange chromatographic column filled with $1.8 \mathrm{ml}$ of AG1-X8 resin (Bio-Rad, Hercules, CA, USA, 100-200 meshes) following previously published methods (Rouxel et al., 2006). After adsorption of Ge on the column, $10 \mathrm{ml}$ of $1 \mathrm{~N} \mathrm{HF}$ and $2 \mathrm{ml}$ of $\mathrm{H}_{2} \mathrm{O}$ was passed through the column to elute the remaining matrix. Germanium was then eluted using $12 \mathrm{ml}$ of $3 \mathrm{~N} \mathrm{HNO}_{3}$ and the solution was taken to dryness at temperature less than $80^{\circ} \mathrm{C}$. After evaporation, the residue was dissolved in $3-5 \mathrm{ml}$ of $0.28 \mathrm{~N} \mathrm{HNO}_{3}$ at $80^{\circ} \mathrm{C}$ for more than $1 \mathrm{~h}$. The final solution was then ready for isotope analysis. 


\subsection{HG-MC-ICP-MS analysis}

Germanium concentration and isotopic ratios were measured using a Thermo-Scientific Neptune MC-ICP-MS coupled with continuous flow hydride generation (HG) system operating at the Pôle Spectrométrie Océan (PSO) of the French Research Institute for Exploitation of the Sea (IFREMER). The instrumental operating conditions and data acquisition parameters are essentially those used in previous studies of Ge isotopes (Rouxel et al., 2006). A small aliquot of sample solution was taken and diluted 3-10 times by addition of $0.28 \mathrm{~N} \mathrm{HNO}_{3}$ for Ge concentration analysis, then the raw sample solution was diluted according to Ge concentration for Ge isotope measurement. Under typical conditions, a minimum of $2 \mathrm{ml}$ of solution was analyzed at a concentration ranging from 5 to $50 \mathrm{ppb}$. The amount of Ge used per analysis varied between 10 and $100 \mathrm{ng}$ for most data presented in this study. Instrumental mass fractionation was corrected using the standard-sample bracketing approach, which involves the measurement of standard (NIST SRM3120a Ge standard solution in this case) before and after each sample. The isotopic results are reported using notation as:

$$
\delta^{x} G e(\%)=\left(\frac{\left.\left({ }^{x} G e\right)^{70} G e\right)_{\text {Sample }}}{\left.\left({ }^{x} G e\right)^{70} G e\right)_{\text {Standard }}}-1\right) * 1000
$$

where $\mathrm{X}$ equals 74,73 , or 72 . The standard isotopic values correspond to the average values of the NIST SRM3120a Ge standard solution analyzed before and after the sample at the same concentration (within 10\%). As discussed in Escoube et al. (submitted for publication), the $\delta^{74} \mathrm{Ge}$ value for bulk silicate Earth is defined at around $0.59 \pm 0.18(2 \sigma) \%$ relative to NIST3120a.

Internal “Ge-Spex WHOI” Ge standard solution (Spex CertiPrep, Lot\# 11-160GE, [Ge] $=100 \mu \mathrm{g} / \mathrm{g}$ in $2 \% \mathrm{HNO}_{3}$ ) was used following the same dissolution and chemical purification processes as ordinary samples, and yielded Ge recovery ratios of 86.9\%-98.1\% and $\delta^{74} \mathrm{Ge}$ values ranging from $-0.66 \%$ o to $-0.80 \%$, which are indistinguishable from the direct measured $\delta^{74} \mathrm{Ge}$ value $(-0.64 \%$ ) within an uncertainty of $0.2 \%$ (Escoube et al., submitted for publication), indicating there is no Ge isotopic fractionation during the sample preparation processes (Table 3). 


\subsection{Ge concentration analysis}

224

We weighed $50 \mathrm{mg}$ of sample into PTFE digestion vessel. Samples were first dissolved by $1 \mathrm{ml}$ concentrated $\mathrm{HF}$ and $3 \mathrm{ml}$ concentrated $\mathrm{HNO}_{3}$ at a temperature of $195^{\circ} \mathrm{C}$ for $48 \mathrm{~h}$ and distilled to dryness on a hot plate. The residue was then re-dissolved in $2 \mathrm{ml}$ concentrated $\mathrm{HNO}_{3}$ at a temperature of $130^{\circ} \mathrm{C}$ for $10 \mathrm{~h}$. After cooling, $500 \mathrm{ng} \mathrm{Rh}$ was added into the solution as an internal standard. The final solution was adjusted to $50 \mathrm{ml}$ by the addition of the distilled deionized water and was determined directly by a ELAN DRC-e ICP-MS at the Institute of Geochemistry, Chinese Academy of Sciences. Digestion and analysis of international reference material GSR-1 was performed following the same procedures. Analytical precision of Ge concentration was estimated to be better than $8 \%$.

\section{Results}

The analytical results (including duplicate analysis) of the Ge isotope compositions of different samples of various types from the LGD are presented in Table 3, as well as the USGS coal standard CLB-1 and the "Ge-Spex WHOI” standard solution. A comparison of $\delta^{74} \mathrm{Ge}$ values of the samples from the LGD with other published values for Earth and planetary materials is presented in Fig. 3.

\subsection{Ge isotope composition of Ge-rich lignite}

Ge-rich lignite samples from the LGD show a large spread in Ge concentrations, ranging from 2.64 to $2585 \mathrm{ppm}$, and their $\delta^{74} \mathrm{Ge}$ values vary from $-2.59 \%$ to $4.72 \%$, yielding an overall range of 7.31 per mil for all data available (Fig.3). The $\delta^{74}$ Ge values are negatively correlated with Ge concentrations, and $\delta^{74} \mathrm{Ge}$ values decrease with increasing Ge concentrations in Ge-rich lignite (Fig. 4). For Ge-rich lignite samples from the Dazhai ore block, $\delta^{74} \mathrm{Ge}=-0.0018[\mathrm{Ge}]+2.45, \mathrm{r}=0.85, \mathrm{n}=16$; For these samples from the Zhongzhai ore block, with an exception of one sample (ZZ-53), $\quad \delta^{74} \mathrm{Ge}=-0.0008[\mathrm{Ge}]+2.85, \mathrm{r}=0.67, \mathrm{n}=21$. Lignite samples with low Ge concentrations $(<500 \mathrm{ppm})$ tend to show positive $\delta^{74}$ Ge values, while $\delta^{74} \mathrm{Ge}$ values of lignite samples with high Ge concentrations (> $1000 \mathrm{ppm}$ ) are close to zero or 
negative.

Moreover, $\delta^{74} \mathrm{Ge}$ values and Ge concentrations show opposite covariant trends in different profiles of coal seams from the LGD. In cross-section A at Dazhai, the coal seams are about $10 \mathrm{~m}$ in thickness with sandstones in the hanging wall and siltstones in the footwall. Germanium is notably concentrated in the lower portion of the coal seams (Fig.5a), while $\delta^{74} \mathrm{Ge}$ values show a peak of $3.55 \%$ in the middle portion (Fig.5b). In cross-section B at Zhongzhai, thin coal seams with siliceous limestone as hanging wall rock and sandstone as footwall rock were interlayered with sandstone. Germanium is clearly concentrated at the top and the bottom of the upper thin coal seam (Fig.5c), while $\delta^{74}$ Ge values generally increased (up to $4.72 \%$ ) in the middle of three thin coal seams in this section (Fig.5d). In cross-sections C and D, the coal seams were interbedded with chert and/or claystone at Zhongzhai (Fig.5e and Fig.5g). Ge-rich lignite samples close to chert show higher Ge concentrations (between 1382 and $2431 \mathrm{ppm}$ ) and lower $\delta^{74}$ Ge values (between $0.49 \%$ and $1.59 \%$ ), compared to those values in section $B$.

\subsection{Ge isotope composition of hydrothermal chert and limestone}

The Ge concentrations of 10 hydrothermal chert samples from the LGD range from 21.6 to 356 ppm, and two samples (ZZ-57 and ZZ-19) with high Ge concentrations (167 and 356 ppm) also show high values of loss on ignition (LOI) (8.70\% and $13.31 \%$, respectively)(Fig.6a). The $\delta^{74}$ Ge values of these cherts vary from $-0.14 \%$ to $2.89 \%$, with a total range of 3 per mil, basically similar to the range of Ge isotopes reported for deep sea cherts and radiolarites by Rouxel et al. (2006) (Fig.3). With an exception of two samples (ZZ-57 and ZZ-19), the most Ge-rich chert samples tend to have the lowest ${ }^{74}$ Ge values $\left(\delta^{74} \mathrm{Ge}=-0.0676[\mathrm{Ge}]+2.94, \mathrm{r}=0.75, \mathrm{n}=8\right)($ Fig.6b)

The 5 limestone samples contain 40.5 to $93.8 \mathrm{ppm}$ Ge, while their $\delta^{74} \mathrm{Ge}$ values range from $0.55 \%$ to $1.87 \%$. Both Ge concentrations and $\delta^{74} \mathrm{Ge}$ values of these limestones are positively correlated with values of LOI $\left(\delta^{74} \mathrm{Ge}=0.0193[\mathrm{Ge}]+0.028, \mathrm{r}=0.79\right.$; LOI $=0.1676$ [Ge] - 4.08, r = 0.87; $\mathrm{n}=5$ ) (Fig.6a and b).

\subsection{Ge isotope composition of granite, sandstone and claystone}


5 granite samples from the Bangmai Basin show homogeneous Ge concentrations (between 1.21 and $1.69 \mathrm{ppm}$ ) and $\delta^{74} \mathrm{Ge}$ values (between $0.55 \%$ and $0.70 \%$ ), and their Ge isotope compositions are within the range of the estimated $\delta^{74}$ Ge value for Bulk Silicate Earth (BSE) (Rouxel et al., 2006; Escoube et al., submitted for publication).

Ge concentrations (about $1.3 \mathrm{ppm}$ ) and $\delta^{74} \mathrm{Ge}$ values (between $0.77 \%$ and $0.80 \%$ ) of two sandstone samples (DZ-1 and ZZ-18, Fig.5a and c) from the roof and bottom of coal seam basically are similar those of the granite, while the other 3 sandstone samples (ZZ-11, ZZ-13, and ZZ-14, Fig.5c) show elevated Ge concentrations (between 3.48 and $8.67 \mathrm{ppm}$ ) and $\delta^{74} \mathrm{Ge}$ values (between 1.63\%o and 2.64\%o).

1 claystone sample (ZZ-50) collected from the claystone interlayer within a coal seam (Fig.5e and f) contains 415 ppm Ge with a lighter Ge isotope composition ( $\delta^{74}$ Ge value of $0.18 \%$ ) relative to the BSE.

\subsection{Ge isotope composition of coal ash, soot and cinder}

The $\delta^{74} \mathrm{Ge}$ values of 11 coal ash samples (ashed at $600^{\circ} \mathrm{C}$ ) of Ge-rich lignite from the LGD range from $-0.31 \%$ to $4.15 \%$, basically similar to values of their corresponding raw coals. The differences between $\delta^{74} \mathrm{Ge}$ values of raw coal and corresponding ash samples are generally less than $0.59 \%$ (Table 3 and Fig. 7). The two soot samples from the LGD have extremely high Ge concentrations (between $1.11 \%$ and $2.20 \%$ ) and lower $\delta^{74}$ Ge values (between 1.25\% and 1.52\%o), while the two cinder samples show lower Ge concentrations (10.1-23.0 ppm), but higher $\delta^{74}$ Ge values (2.69\%o-3.50\%o) (Fig. 8).

\section{Discussion}

\subsection{Closed-system equilibrium fractionation model for Ge isotope variation in Ge-rich} lignite

Based on Urey model (or Bigeleisen-Mayer equation) and high level quantum chemistry calculations, Li et al. (2009) estimated the equilibrium fractionation factors $(\alpha)$ in several Ge isotope systems, including the dominant aqueous $\mathrm{Ge}(\mathrm{OH})_{4}$ and $\mathrm{GeO}(\mathrm{OH})_{3}{ }^{-}$species in seawater, Ge-bearing organic complexes (e.g. Ge-catechol, Ge-oxalic acid and Ge-citric acid), and Ge in quartz- (or opal-), albite-, K-feldspar-, olivine- and sphalerite-like structures. 
According to these estimated equilibrium fractionation factors $(\alpha)$, the light Ge isotope $\left({ }^{70} \mathrm{Ge}\right)$ will be preferentially enriched in organic matter $\left(\alpha_{\text {organic-Ge(OH)4 }}<1\right)$, while the heavy Ge isotope $\left({ }^{74} \mathrm{Ge}\right)$ will be slightly enriched in quartz $\left(\alpha_{\text {quartz-Ge(OH)4 }}>1\right)$, relative to coexisting aqueous $\mathrm{Ge}(\mathrm{OH})_{4}$. Germanium isotope fractionations defined as $[1000 \mathrm{Ln}(\alpha)]$ between 6-coordinated Ge-bearing organic complexes and $\mathrm{Ge}(\mathrm{OH})_{4}(\mathrm{aq})$ and between quartz and $\mathrm{Ge}(\mathrm{OH})_{4}(\mathrm{aq})$ can be up to $-4.9 \%$ and $1.1 \%$ at $25^{\circ} \mathrm{C}$, respectively.

If we approximate the equilibrium fractionation factor between coal and water $\left(\alpha_{\mathrm{Coal}-\mathrm{Ge}(\mathrm{OH}) 4}\right)$ as identical to the fractionation factor between Ge-catechol and water $\left(\alpha_{\mathrm{Ge}-\mathrm{catechol-Ge(OH}) 4}\right)$, we can further deduce that the Ge isotope compositions of coal-associated quartz will be distinctly heavier (up to $6 \%$ at $25^{\circ} \mathrm{C}$ ) than those of coal in the case of an isotopically closed system at equilibrium. However, our analyzed $\delta^{74}$ Ge values of cherts (between $-0.14 \%$ and 2.89\%o) are obviously lower than those of Ge-rich lignite samples with low Ge concentration (up to 4.72\%o). Moreover, a closed-system equilibrium fractionation model also could not explain the negative correlation between Ge concentration and $\delta^{74} \mathrm{Ge}$ values of Ge-rich lignite samples, and the opposite covariant trend between $\delta^{74} \mathrm{Ge}$ values and Ge concentrations in different profiles from the LGD.

\subsection{Open system Rayleigh fractionation model for Ge isotope variation in Ge-rich lignite}

For non-traditional isotope systems, the isotopic fractionation during reduction of $\mathrm{Se}(\mathrm{VI})$ and $\mathrm{Cr}(\mathrm{VI})$ in solution (Johnson et al., 1999; Ellis et al., 2002), sorption of Ge (IV) on goethite (Galy et al., 2002), and adsorption of aqueous monosilicic acid onto iron oxide (Delstanche et al., 2009) have been shown to follow a Rayleigh fractionation process. In particular, Galy et al. (2002) deduced that a similar fractionation mechanism might be expected to occur during Ge sorption onto organic matter. In this section, we calculate the Ge isotopic fractionations produced by a Rayleigh fractionation process during Ge sorption onto coal (i.e. complexation of $\mathrm{Ge}$ in solution with organic functional groups in coal, see Manskaya et al., 1972; Bernstein, 1985; Pokrovski and Schott, 1998b) and during the precipitation of quartz.

For open system isotopic exchange, the Ge isotopic ratio of the solution from which Ge is precipitated in coal can be described by the following equation (Rayleigh, 1896): 


$$
\frac{\left[{ }^{74} \mathrm{Ge} /{ }^{70} \mathrm{Ge}\right]}{\left[{ }^{74} \mathrm{Ge} /{ }^{70} \mathrm{Ge}\right]_{\mathrm{i}}}=f^{(\alpha-1)}
$$

where $\left[{ }^{74} \mathrm{Ge} /{ }^{70} \mathrm{Ge}\right]_{\mathrm{i}}$ and ${ }^{74} \mathrm{Ge} /{ }^{70} \mathrm{Ge}$ represent the initial and instantaneous isotopic ratio of Ge in solution; and $f$ is the fraction of Ge remaining in solution (1- $f$ is the fraction of Ge precipitated). Cast in terms of $\delta^{74} \mathrm{Ge}$ values, for the isotopic composition of the solution $\left(\delta^{74} \mathrm{Ge}_{\text {solution}}\right)$, Equation (2) becomes:

$$
\delta^{74} \mathrm{Ge}_{\text {solution }}=\left(1000+\delta^{74} \mathrm{Ge}_{\mathrm{i}}\right) * f^{(\alpha-1)}-1000
$$

where $\delta^{74} \mathrm{Ge}_{\mathrm{i}}$ is the initial Ge isotopic composition of solution. Then, the instantaneous $\delta^{74} \mathrm{Ge}$ value of coal $\left(\delta^{74} \mathrm{Ge}_{\text {coal }}\right)$ is given by:

$$
\delta^{74} G e_{\text {coal }}=\delta^{74} G e_{\text {solution }}+(\alpha-1) * 1000
$$

and the $\delta^{74} \mathrm{Ge}$ values for the accumulated or total coal $\left(\delta^{74} \mathrm{Ge}_{\text {coal,Tot }}\right)$ at any time is expressed by:

$$
\frac{\left(1000+\delta^{74} G e_{\text {coal, Tot }}\right)}{\left(1000+\delta^{74} G e_{i}\right)}=\frac{1-f^{\alpha}}{1-f}
$$

Similarly, Ge isotope fractionation produced by Rayleigh fractionation processes during precipitation of quartz also can be calculated using the foregoing equations.

For calculations, we assumed that $\alpha$ is constant and that $\delta^{74} \mathrm{Ge}_{\mathrm{i}}$ is $1.70 \%$, which is close to the Ge isotopic composition ( $\delta^{74} \mathrm{Ge}$ value of $1.50 \%$ ) for low temperature hydrothermal solution formed in volcanic environments (Rouxel et al., 2008). The mean random vitrinite (or huminite in lignite) reflectance $\left(\mathrm{R}_{\mathrm{m}}\right.$ in \%) of Ge-rich lignite samples from the LGD range from $0.39 \%$ to $0.60 \%(0.48 \%$ on average, $n=27)$, and based on the relationship between $R_{m}$ and maximum burial temperature $\left(T_{\max }\right.$ in $\left.{ }^{\circ} \mathrm{C}\right)$ (Barker and Pawlewicz, 1986), the calculated $T_{\max }$ values vary from $33.1^{\circ} \mathrm{C}$ to $88.4^{\circ} \mathrm{C}$, with an average of $60^{\circ} \mathrm{C}(\mathrm{n}=27$; Table 4). The values of $\alpha_{\mathrm{Coal-Ge(OH)4}}$ (approximated by $\alpha_{\mathrm{Ge-catechol-Ge(OH)4})}$ and $\alpha_{\text {quartz-Ge(OH)4 }}$ were calculated from the formula (1000 $\left.\mathrm{Ln} \alpha=\mathrm{A} 10^{6} / \mathrm{T}^{2}+\mathrm{B}\right)$ in $\mathrm{Li}$ et al. (2009) at $\mathrm{T}=50^{\circ} \mathrm{C}$. Simulative results show that: (1) both the instantaneous $\delta^{74} \mathrm{Ge}$ values of solution and coal increase with fraction of Ge precipitated in coal and show a greater range (more than 14 per mil) during the sorption of Ge in coal (Fig. 9a); (2) while precipitation of quartz will lead to decreasing of instantaneous $\delta^{74}$ Ge values of solution and quartz (Fig. 9b).

Considering that (1) the contents of humic acids in Ge-rich lignite samples from the 
LGD range from $11.58 \%$ to $33.39 \%$, (2) the quantity of Ge absorbed $\left(\mathrm{Ge}_{\mathrm{absorb}}\right.$ in $\left.\mu \mathrm{g}\right)$ on humic acids extracted from peat is positively correlated with Ge concentration $\left([\mathrm{Ge}]_{\text {solution }}\right.$ in g/L) in solution $\left(\mathrm{Ge}_{\mathrm{absorb}}=1.80[\mathrm{Ge}]_{\text {solution }}-29.64, \mathrm{r}=0.98, \mathrm{n}=6\right)$ (Zhang et al., 1987), and (3) Ge in mineralized coal seams from the LGD is mainly associated with organic matter, we can simply deduce that quantity of Ge absorbed in coal ([Ge $\left.]_{\text {coal }}\right)$ will also be positively correlated with Ge concentration in solution ([Ge $\left.]_{\text {solution }}\right)$. The relation between $[\mathrm{Ge}]_{\text {coal }}$ and the initial Ge concentration in solution $\left([\mathrm{Ge}]_{\mathrm{i}}\right)$ can be expressed as:

$$
[\mathrm{Ge}]_{\mathrm{coal}}=k^{*}[\mathrm{Ge}]_{\text {solution }}=k^{*}[\mathrm{Ge}]_{\mathrm{i}} * f
$$

with $\mathrm{k}$ being the partition coefficient factor between solution and coal.

Then, Eq. (4) can be written as:

$$
\delta^{74} G e_{\text {coal }}=\left(1000+\delta^{74} \mathrm{Ge}_{\mathrm{i}}\right) * f^{(\alpha-1)}-1000+(\alpha-1) * 1000
$$

Replacing $f$ with $[\mathrm{Ge}]_{\text {coal }} / k^{*}[\mathrm{Ge}]_{\mathrm{i}}, \delta^{74} G e_{\text {coal }}$ can be related to $[\mathrm{Ge}]_{\text {coal }}$ by

$$
\delta^{74} G e_{\text {coal }}=A^{*}[G e]_{\text {coal }}^{\alpha-1}+B
$$

where

$$
A=\frac{\left(\delta^{74} G e_{\mathrm{i}}+1000\right)}{\left(k^{*}[G e]_{\mathrm{i}}\right)^{\alpha-1}}, \quad B=(\alpha-1) * 1000-1000
$$

For Ge-rich lignite samples derived from the same hydrothermal source, $A$ and $B$ can be regarded as constants. The calculated values of $\alpha$ between organic-complexes and $\mathrm{Ge}(\mathrm{OH})_{4}(\mathrm{aq})$ are less than 1 ( $\mathrm{Li}$ et al., 2009), and $\alpha-1$ is a negative value, therefore $\delta^{74} G e_{\text {coal }}$ value will be negatively correlated with $[\mathrm{Ge}]_{\text {coal }}$. This is fully consistent with the observed negative correlation between $\delta^{74}$ Ge values and Ge concentrations of Ge-rich lignite samples from the LGD (Fig. 4).

An initial Ge solution concentration of $30 \mathrm{ppb}$ and a constant attenuation coefficient of $3 \mathrm{ppb} / \mathrm{m}$ were chosen to schematically monitor the variation of instantaneous $[\mathrm{Ge}]_{\text {solution }}$ and $[\mathrm{Ge}]_{\text {coal }}$ along the migratory direction of Ge plume, when ascending hydrothermal solution penetrates coal seam. Using Eq. (3) and Eq. (4), we can also simultaneously simulate the variation of instantaneous $\delta^{74} \mathrm{Ge}_{\text {solution }}$ and $\delta^{74} \mathrm{Ge}_{\text {coal }}$. The results (Fig. 10) indicate that both $[\mathrm{Ge}]_{\text {solution }}$ and $[\mathrm{Ge}]_{\text {coal }}$ decrease from the bottom to the top, while the values of $\delta^{74} \mathrm{Ge}_{\text {solution }}$ and $\delta^{74} \mathrm{Ge}_{\text {coal }}$ increase from the bottom to the top of a particular coal seam. Such an opposite 
covariant trend between $[\mathrm{Ge}]_{\text {coal }}$ and $\delta^{74} \mathrm{Ge}_{\text {coal }}$ is consistent with the actual variation of $\delta^{74} \mathrm{Ge}$ values and Ge concentrations of Ge-rich lignite samples in the mid-lower part of cross-section A from the LGD (Fig.5a and b).

There are many factors controlling the distribution of Ge in coal, such as thickness of the coal seam, depth of burial of the coal seam, permeability of the country rocks, ground water level, initial Ge concentration of the Ge-bearing solution, migratory direction of the Ge-bearing solution, the width of the front edge of the Ge-bearing solution, as well as the distance between the coal seam and central passage of the Ge-bearing solution (Smivnov, 1977; Yudovich, 2003; Qi et al., 2007a). The combination of these factors might vary among different parts of one particular coal seam within the same coal deposit. Generally, Ge tends to be concentrated at the top or the bottom of a coal seam, obeying 'Zilbermints Law' (Yudovich, 2003). For thin coal seams interlayered with sandstone, such as the coal seams in cross-section B (Fig.5c), when Ge-bearing solution reached the coal seam, the high permeability of sandstone favors rapid migration and diffusion of Ge-bearing solution through the sandstone, and the coal samples from the bottom of the upper coal seam and those from the top of the lower coal seam, which distributed near the interlayered sandstone, have more opportunity to interact with Ge-bearing solution and tend to enrich more Ge relative to coal samples in the middle. A similar scenario may have also occurred in the upper part of section A from the LGD. As mentioned earlier, coal samples near the top or the bottom will preferentially incorporate the light $\mathrm{Ge}$ isotope $\left({ }^{70} \mathrm{Ge}\right)$, producing a remaining aqueous solution with a lower Ge concentration but enriched in heavy Ge isotopes. When this remaining aqueous solution interacted with coal samples in the middle part of the coal seam, those coal samples will consequently show lower Ge concentrations and elevated $\delta^{74}$ Ge values as shown in Fig. 5c and d.

\subsection{Ge isotope variation in other samples from LGD}

Germanium concentrations in hydrothermal chert and limestone samples from the LGD are two orders of magnitude higher than those in sedimentary carbonate rocks $(0.09 \mathrm{ppm}$ on average, Bernstein, 1985) and in deep-sea cherts (0.23-1.02 ppm, Kolodny and Halicz, 1988; 0.39-1.08 ppm, Rouxel et al., 2006). The distinct correlation between LOI and Ge 
concentration of limestone samples indicate the addition of Ge-rich organic matter. The Ge isotopic compositions of limestone samples are basically similar to those of chert samples (Table 1 and Fig.3), indicating the equilibrium fractionation factors $(\alpha)$ between calcite and $\mathrm{Ge}(\mathrm{OH})_{4}(\mathrm{aq})$ might be close to that between quartz and $\mathrm{Ge}(\mathrm{OH})_{4}(\mathrm{aq})$. The opposite $\mathrm{Ge}$ isotopic fractionation factors between quartz, coal and aqueous $\mathrm{Ge}(\mathrm{OH})_{4}$ suggest that the precipitation of Ge in quartz will suppress Ge isotopic fractionation caused by sorption of coal. This might be the reason why the measured Ge isotopic fractionations (about -0.1 to 1.3 per mil) between chert and nearby Ge-rich lignite samples in Fig.5f and Fig.5h are less than that expected from the equilibrium fractionation model (up to $6 \%$ at $25^{\circ} \mathrm{C}$ ). Therefore, the Ge isotopic composition of chert might record the competitive fractionation produced by precipitation of quartz and sorption by coal.

The difference in the measured isotopic composition for reactant and product most closely match that of the true fractionation factor at the beginning of the reaction (Johnson et al., 2004). Using the calculated values (0.99557 and 1.000921) of $\alpha$ at $\mathrm{T}=50^{\circ} \mathrm{C}$ along with the minimum $\delta^{74}$ Ge value (-2.59\%) of coal and the maximum $\delta^{74}$ Ge value (2.89\%) of chert, we can approximately deduce the 'true' initial $\delta^{74}$ Ge values of Ge-bearing solution range from $1.84 \%$ o to $1.97 \%$.

Compared to the low Ge concentrations (about $1.3 \mathrm{ppm}$ ) and $\delta^{74} \mathrm{Ge}$ values (between $0.77 \%$ and $0.80 \%$ ) of the two sandstone samples from the roof and the bottom of the coal seam, the elevated Ge concentrations (between 3.48 and $8.67 \mathrm{ppm}$ ) and $\delta^{74} \mathrm{Ge}$ values (between $1.63 \%$ and $2.64 \%$ o) of sandstone samples in middle part of coal seam may also be attributed to the addition of organic matter.

\subsection{Ge isotope fractionation during coal combustion}

The mobility of trace elements during combustion depends on their affinities and concentrations, physical changes and chemical reactions of these elements with other volatile elements, and combustion technology (temperature, time of exposure, type of ash generation, etc) (Querol et al., 1995). For any particular coal, combustion temperature might be one of the most important factors controlling elemental behavior during coal combustion. If combustion temperature is higher than the melting point or boiling point of one element, the element will 
be vaporized. The ashing temperature of our analyzed coal ash samples $\left(600^{\circ} \mathrm{C}\right)$ is less than the melting point of Ge metal $\left(937^{\circ} \mathrm{C}\right)$. Therefore, there is no distinct loss of Ge and Ge isotope fractionation during low temperature ashing. This means that low temperature ashing might be an alternative way to enhance Ge concentrations and to overcome matrix effects from high organic carbon content during analysis of organic-rich geological samples with low Ge concentrations.

However, for high temperature combustion, this situation may be quite different. In a typical coal-fired power station, combustion takes place in a furnace operating at temperatures $>1400^{\circ} \mathrm{C}$ (Clarke, 1993). Similar to the fractionation of $\mathrm{Zn}, \mathrm{Cd}$ and $\mathrm{Hg}$ isotopes between dust or gas and slag from $\mathrm{Pb}-\mathrm{Zn}$ refinery plants (Cloquet et al., 2006, 2008; Sivry et al., 2008; Sonke et al., 2010), high temperature coal combustion also fractionates Ge isotopes, with Ge isotopic compositions of soot (volatile component) are distinctly lighter (up to 2.25 per mils for $\delta^{74} \mathrm{Ge}$ ) than those of cinder (solid residue). The elements associated with sulfides, sulfates and organic matter in coal show the highest extraction rates during combustion (Querol et al., 1996). As mentioned earlier, Ge is mainly associated with organic matter in coal, and similar to the fractionation of $\mathrm{Cd}(0)$ during evaporation (Wombacher et al., 2004), the distinct Ge isotope fractionation between soot and cinder samples might also be attributed to evaporation-condensation processes during high temperature coal combustion.

Both $\mathrm{Ge}$ and some potentially hazardous elements (i.e. $\mathrm{Zn}, \mathrm{Pb}$, As, and $\mathrm{Cd}$ ) were classified in the same moderately volatile group, and these elements tend to be enriched in the fly ash and depleted in bottom ash (Clarke, 1993). Depending on the raw concentration of those elements in coal or $\mathrm{Pb}-\mathrm{Zn}$ ore (mostly sphalerite), Ge and other potentially hazardous elements (Zn, $\mathrm{Pb}$, As, and $\mathrm{Cd})$ might be preferentially and simultaneously enriched in dust or soot during high temperature coal combustion and $\mathrm{Pb}-\mathrm{Zn}$ refining processes. Our analytical results show that the concentrations of $\mathrm{Zn}, \mathrm{Pb}, \mathrm{As}$, and $\mathrm{Cd}$ in Ge-rich soot from the LGD can be up to 9060 ppm, 5681 ppm, 406 ppm, and 119 ppm, respectively (Table 5). The average Ge concentration (5.7 ppm) in USA coals is higher than that (1.6 ppm) of the upper continental crust (Taylor and McLennan, 1985; Finkelman, 1993), and Ge is commonly enriched in sphalerite (Ge concentrations range from a few ppm to about 3000 ppm, Bernstein, 1985 and reference therein). Therefore, Ge isotopes have great potential to be a tracer of sources of Ge 
and other heavy metal pollution caused by high temperature industrial processes (coal combustion and $\mathrm{Pb}-\mathrm{Zn}$ refining) in the environment.

It has been also shown that rivers draining industrial regions with significant coal combustion are contaminated with Ge leached from fly ash particles, resulting in Ge/Si ratios up to tenfold above the naturally weathered background (Froelich et al., 1985). For example, large rivers such as Mississippi, St. Lawrence, Changjiang and Danube have Ge/Si ratios well in excess of $1 \times 10^{-6}(\mathrm{~mol} / \mathrm{mol})$ which has been attributed to significant coal combustion and associated Ge mobilization in their watersheds (Mortlock and Froelich, 1987). Hence, considering the generally positive ${ }^{74} \mathrm{Ge}$ values observed in coal, which is in marked contrast with the generally negative ${ }^{74} \mathrm{Ge}$ values in sulfide-rich ore deposits (Escoube et al., submitted for publication), Ge isotopic compositions of rivers and probably coastal oceans should provide a useful mean to discriminate anthropogenic Ge sources in the environment.

\section{Conclusions}

Large Ge isotopic fractionation (up to 7.31\%o) and a negative correlation between $\delta^{74} \mathrm{Ge}$ values and Ge concentrations were found in the Ge-rich lignite samples from the Lincang Ge deposit. Lignite samples with low Ge concentrations ( $<500 \mathrm{ppm})$ tend to show positive $\delta^{74} \mathrm{Ge}$ values, while $\delta^{74} \mathrm{Ge}$ values of lignite samples with high Ge concentrations (>1000 ppm) are close to zero or negative. In profiles, Ge mainly concentrated in the top or the bottom, such that high values of $\delta^{74} \mathrm{Ge}$ are usually found in the middle part of coal seams. The $\delta^{74} \mathrm{Ge}$ values of interlayered hydrothermal cherts and limestones in Ge-rich coal seams range from $-0.14 \%$ to $2.89 \%$ and from $0.55 \%$ o to $1.87 \%$, respectively. The variations in $\delta^{74} \mathrm{Ge}$ values of Ge-rich lignite and chert samples can be well described by an open-system Rayleigh fractionation model, indicating that preferential enrichment of the light isotope $\left({ }^{70} \mathrm{Ge}\right)$ in coal might be the main factor controlling Ge fractionation in Ge-rich lignite, while the Ge isotopic composition of hydrothermal chert (and possibly limestone) in the coal seam might record the fractionation produced by dynamic equilibrium between precipitation of quartz and sorption to coal. Moreover, elevated Ge concentrations and/or $\delta^{74} \mathrm{Ge}$ values of some chert, limestone, sandstone, and claystone samples may be attributed to the addition of Ge-rich organic matter. Furthermore, the distinct Ge isotopic fractionation between soot and cinder (up to 2.25 per 
518 mil for $\delta^{74} \mathrm{Ge}$ ) indicate high temperature coal combustion also fractionates Ge isotopes. The

519 distinct enrichment of potentially hazardous elements (i.e., $\mathrm{Pb}, \mathrm{Cd}$, and $\mathrm{As}$ ) and $\mathrm{Ge}$ in soot

520 from coal combustion, as well as the common enrichment of Ge in sphalerite, highlight the

521 possibility of Ge isotopes as a tracer of sources of heavy metal pollution caused by high

522 temperature industrial processes (coal combustion and $\mathrm{Pb}-\mathrm{Zn}$ refining) in the environment.

523

524

\section{Acknowledgments}

525

526

This project was jointly supported by Europole Mer, Knowledge Innovation Program of Chinese Academy of Sciences (Grant No. KZCX2-YW-Q04-01), and Natural Sciences

528 Foundation of China (Grant No. 41073041, 40930425). The authors thank Emmanuel Ponzevera and Dan Asael for their assistance during sample preparation and analysis at IFREMER and IUEM. We thank Stefan Lalonde and two anonymous reviewers for helpful comments and suggestions on the manuscript. 


\section{References}

Arnórsson, S., 1984. Germanium in Icelandic geochermal systems. Geochem. Cosmochem. Acta 48, 2489-2502.

Barker, C.E., Pawlewicz, M.J., 1986. The correlation of vitrinite reflectance with maximum temperature in humic organic matter. Lecture Notes in Earth Sciences 5, 79-93.

Bernstein, L.R., 1985. Germanium geochemistry and mineralogy. Geochem. Cosmochem. Acta 49, 2409-2422.

Clarke, L.B., 1993. The fate of trace elements during combustion and gasification: an overview. Fuel, 72, 731-736.

Cloquet, C., Carignan, J., Lehmann, M.F., Vanhaecke, F., 2008. Variation in the isotopic composition of zinc in the natural environment and the use of zinc isotopes in biegeosciences: A review. Anal. Bioanal. Chem. 390, 451- 463.

Cloquet, C., Carignan, J., Libourel, G., Sterckeman, T., Perdrix, E., 2006. Tracing source pollution in soils using cadmium and lead isotopes. Environ. Sci. Technol. 40, 2525- 2530.

Delstanche, S., Opfergelt, S., Cardinal, D., Elsass, F., Andre, L., Delvaux, B., 2009. Silicon isotopic fractionation during adsorption of aqueous monosilicic acid onto iron oxide. Geochem. Cosmochem. Acta 73, 923-934.

Du, G., Zhuang, X. G., Querol, X., Izquierdo, M., Alastuey, A., Moreno, T., Font, O., 2009. Ge distribution in the Wulantuga high-germanium coal deposit in the Shengli coalfield, Inner Mongolia, northeastern China. Int. J. Coal Geol.78, 16-26.

Ellis, A.S., Johnson, T.M., Bullen, T.D., 2002. Cr isotopes and the fate of hexavalent chromium in the environment. Science 295: 2060-2062.

Escoube, R., Rouxel, O., Luais, B., Ponzevera, E., Donard, O., submitted for publication. Intercomparison study of Germanium Isotope composition of Natural and Synthetic Geochemical Reference Materials. Geostandards and Geoanalytical Research (submitted).

Evans, M.J. and Derry, L.A., 2002. Quartz control of high germanium/silicon ratios in geothermal waters. Geology 30, 1019-1022.

Finkelman, R.B., 1993. Trace and minor elements in coal. Organic Geochemistry (eds. M. H. Engel, S. A. Macko). Plenum, New York, pp. 593-607.

Froelich, P.N., Hambrick, G..A., Andreae, M.O., Mortlock, R.A., Edmond, J.M., 1985. The Geochemistry of Inorganic Germanium in Natural Waters, J. Geophys. Res., 90(C1), 1133-1141.

Galy, A., Pokrovsky, O.S., Shott, J., 2002. Ge-isotopic fractionation during its sorption on goethite: an experimental study. Geochim. Cosmochim. Acta 66, A259.

Han, Y.R., Yuan Q.B., Li, Y.H., 1994. Dazhai superlarge uranium-bearing germanium deposit in Western Yunnan-Region metallogenic geological conditions and prospect. Beijing: Nuclear Energy Press, p.3-12 (in Chinese with English abstract).

Höll, R., Kling, M., Schroll, E., 2007. Metallogenesis of germanium - a review. Ore Geology Reviews 30, 145-180.

Hu, R.Z., Qi, H.W., Zhou, M.F., Su, W.C., Bi, X.W., Peng, J.T., Zhong, H., 2009. Geological and geochemical constraints on the origin of the giant Lincang coal seam-hosted 

Geochemistry of non-traditional stable isotopes (eds. C. M. Johnson, B. L. Beard, F. Albarède). Reviews in Mineralogy and Geochemistry 55, pp. 1-24.

Johnson, T.M., Herbel, M.J., Bullen, T.D., Zawislanski, P.T., 1999. Selenium isotope ratios as indicators of selenium sources and oxyanion reduction. Geochim. Cosmochim. Acta 63, $2775-2783$.

Kolodny, Y., Halicz, L., 1988. The geochemistry of germanium in deep-sea cherts. Geochim. Cosmochim. Acta 52, 2333-2336.

Li, X.F., Liu, Y., 2010. First-principles study of Ge isotope fractionation during adsorption onto Fe(III)-oxyhydroxides surfaces. Chem. Geol. 278, 15-22.

Li, X.F., Zhao, H., Tang, M., Liu, Y., 2009. Theoretical prediction for several important equilibrium Ge isotope fractionation factors and geological implications. Earth Planet. Sci. Lett. 287, 1-11.

Li, Y.H., 2000. The geological characteristics of Lincang Ge deposit. Yunnan Geology 19, 263-269 (in Chinese with English abstract).

Luais, B., 2007. Isotopic fractionation of germanium in iron meteorites: Significance for nebular condensation, core formation and impact processes. Earth Planet. Sci. Lett. 262, 21-36.

Manskaya, S.M., Kodina, V.N., Generalova, V.N., Kravtsova, R.P., 1972. Interaction between germanium and lignin structure in the early stages of formation of coal. Geokhimiya 5, 600-609.

Mortlock, R.A., Froelich, P.N., 1986. Hydrothermal germanium over the Southern East Pacific Rise. Science 231, 43-45.

Mortlock, R.A., Froelich, P.N., 1987. Continental weathering of germanium: Ge/Si in the global discharge. Geochim. Cosmochim. Acta 51, 2075-2082.

Mortlock, R.A., Froelich, P.N., Feely, R.A., Massoth, G.J., Butterfield, D.A., Lupton, J.E., 1993. Silica and germanium in Pacific Ocean hydrothermal vents and plums. Earth Planet. Sci. Lett. 119, 365-378.

Pokrovski, G..S., Schott, J.A., 1998b. Experimental study of the complexation of silicon and germanium with aqueous organic species: implications for germanium and silicon transport and Ge/Si ratio in natural waters. Geochim. Cosmochim. Acta 62, 3413-3428.

Pokrovski, G.S., Schott, J.A., 1998a. Thermodynamic properties of aqueous Ge(IV) hydroxide complexes from 25 to $350{ }^{\circ} \mathrm{C}$ : Implications for the behavior of $\mathrm{Ge}$ and the $\mathrm{Ge} / \mathrm{Si}$ ratio in hydrothermal fluids. Geochim. Cosmochim. Acta 62, 1631-1642.

Qi, H.W., Hu, R.Z., Su, W.C., Qi, L., Feng, J.Y., 2004. Continental hydrothermal sedimentary siliceous rock and genesis of superlarge germanium (Ge) deposit hosted in coal: a study from the Lincang Ge deposit, Yunnan, China. Sciences in China (Series D) 47, 973-984.

Qi, H.W., Hu, R.Z., Zhang, Q., 2007a. Concentration and distribution of trace elements in lignite from the Shengli Coalfield, Inner Mongolia, China: Implications on origin of the associated Wulantuga Germanium Deposit. Int. J. Coal Geol. 71, 129-152. 
Qi, H.W., Hu, R.Z., Zhang, Q., 2007b. REE Geochemistry of the Cretaceous lignite from Wulantuga Germanium Deposit, Inner Mongolia, Northeastern China. Int. J. Coal Geol. 71, 329-344.

Querol, X., Fernández-Turiel, J.L., López-Soler, A., 1995. Trace elements in coal and their behaviour during combustion in a large power station. Fuel 74, 331-343.

Querol, X., Juan, R., López-Soler, A., Fernández-Turiel, J.L., Ruiz, C.R., 1996. Mobility of trace elements from coal and combustion wastes. Fuel 75, 821-838.

Rayleigh, J.W.S., 1896. Theoretical considerations respecting the separation of gases by diffusion and similar processes. Philo. Mag. 42, 493.

Rouxel, O., Escoube, R., Donard, O.F.X., 2008. Measurement of Germanium isotope composition in marine samples by hydride generation coupled to MC-ICP-MS. Goldschmidt Conference Abstracts, A809.

Rouxel, O., Galy, A., Elderfield, H., 2006. Germanium isotopic variations in igneous rocks and marine sediments. Geochim. Cosmochim. Acta 70, 3387-3400.

Seredin, V.V., Danilcheva, J., 2001. Coal-hosted Ge deposits of the Russian far east. In Mineral Deposits at the Beginning of the 21st Century (eds. A. Piestrzyski). Swets \& Zeitlinger Publishers, Lisse, The Netherlands, pp. 89-92.

Seredin, V.V., Finkelman, R.B., 2008. Metalliferous coals: A review of the main genetic and geochemical types. Int. J. Coal Geol. 76, 253-289.

Siebert, C., Ross, A., McManus, J., 2006. Germanium isotope measurements of high temperature geothermal fluids using double-spike hydride generation MC-ICP-MS. Geochim. Cosmochim. Acta 70, 3986-3995.

Sivry, Y., Riotte, J., Sonke, J.E., Audry, S., Schäfer, J., Viers, J., Blanc, G., Freydier, R., Dupré, B., 2008. Zn isotopes as tracers of anthropogenic pollution from Zn-ore smelters The Riou Mort-Lot River system. Chem. Geol. 255, 295-304.

Smirnov, V.I., 1977. Ore deposits of the USSR, vol. I and II. Pitman Publishing, London. 1286 pp.

Sonke, J.E., Schäfer, J., Chmeleff, J., Audry, S., Blanc, G., Dupré, B., 2010. Sedimentary mercury stable isotope records of atmospheric and riverine pollution from two major European heavy metal refineries. Chem. Geol. 279, 90-100.

Taylor, S.R., McLennan, S.M., 1985. The continental crust: its composition and evolution. Blackwell Scientific Publications, Oxford, pp. 9-67.

Valkovic, V., 1983. Trace Elements in Coal, vol. 1. CRC Press, pp. 133-138.

Wombacher, F., Rehkamper, M., Mezger, K., 2004. Determination of the mass-dependence of cadmium isotope fractionation during evaporation. Geochim. Cosmochim. Acta 68, 23492357.

Yudovich, Y.E., 2003. Notes on the marginal enrichment of Germanium in coal beds. Int. J. Coal Geol. 56, 223-232.

Zhang, S.L., Wang, S.Y., Yin, J.S., 1987. Study on existent forms of germanium in coal, Bangmai Basin, Yunnan. Uranium Geology 3, 266-275 (in Chinese with English abstract).

Zhuang, H.P., Lu, J.L., Fu, J.M., Liu, J.Z., 1998a. Lincang superlarge germanium deposit in 
661 Yunnan Province, China: Sedimentation, Diagenesis, Hydrothermal Process and 662 Mineralization. Journal of China University of Geosciences 9, 129-136.

663 Zhuang, H.P., Lu, J.L., Fu, J.M., Liu, J.Z., Ren, C.G., Zou, D.G.., 1998b. Germanium 664 occurrence in Lincang superlarge deposit in Yunnan, China. Science in China (series D) 41 665 (supplement), 21-27.

666 Zhuang, X.G., Querol, X., Alastuey, A., Juan, R., Plana, F., Lopez-soler, A., Du, G., 2006. 667 Geochemistry and mineralogy of the Cretaceous Wulantuga high-germanium coal deposit 668 in Shengli coal field, Inner Mongolia, Northeastern China. Int. J. Coal Geol. 66, 119-136. 669 
Table $1 \mathrm{Ge}$ content and elemental analysis results of raw lignite samples from the Lincang Ge deposit

\begin{tabular}{llccccccccc}
\hline Sample No. & Sample type & $\begin{array}{c}\mathrm{Ge}^{\mathrm{a}} \\
(\mathrm{ppm})\end{array}$ & $\begin{array}{c}\mathrm{N} \\
(\%)\end{array}$ & $\begin{array}{c}\mathrm{C} \\
(\%)\end{array}$ & $\begin{array}{c}\mathrm{S} \\
(\%)\end{array}$ & $\begin{array}{c}\mathrm{H}^{\mathrm{b}} \\
(\%)\end{array}$ & $\begin{array}{c}\mathrm{O}^{\mathrm{b}} \\
(\%)\end{array}$ & $\begin{array}{c}\text { Moisture } \\
(\%)\end{array}$ & $\begin{array}{c}\text { Ash yield } \\
(\%)\end{array}$ & Total \\
\hline DZ-4 & Ge-rich lignite & 65.8 & 1.53 & 64.66 & 0.63 & 3.95 & 11.27 & 10.08 & 5.90 & 98.02 \\
DZ-5 & Ge-rich lignite & 130 & 1.56 & 63.74 & 0.64 & 4.00 & 10.71 & 9.79 & 7.25 & 97.69 \\
DZ-9 & Ge-rich lignite & 1942 & 1.40 & 62.94 & 1.87 & 3.94 & 10.86 & 9.44 & 6.94 & 97.39 \\
ZZ-6 & Ge-rich lignite & 385 & 1.96 & 60.92 & 0.45 & 3.83 & 11.68 & 9.39 & 12.27 & 100.5 \\
ZZ-9 & Ge-rich lignite & 48.0 & 1.73 & 60.77 & 0.47 & 3.84 & 10.42 & 9.17 & 13.22 & 99.62 \\
ZZ-12 & Ge-rich lignite & 240 & 1.72 & 67.04 & 0.47 & 3.91 & 12.26 & 9.92 & 4.39 & 99.71 \\
ZZ-22 & Ge-rich lignite & 2234 & 1.19 & 65.75 & 0.60 & 3.95 & 10.93 & 10.53 & 6.77 & 99.72 \\
ZZ-46 & Ge-rich lignite & 1382 & 1.38 & 66.84 & 0.57 & 4.16 & 11.28 & 9.26 & 4.77 & 98.26 \\
ZZ-48 & Ge-rich lignite & 2431 & 0.91 & 63.82 & 0.51 & 4.15 & 10.08 & 7.94 & 10.05 & 97.46 \\
ZZ-64 ${ }^{c}$ & Ge-free lignite & 0.422 & 1.14 & 53.82 & 6.42 & 3.88 & 15.69 & 8.30 & 11.34 & 100.59 \\
ZZ-66 ${ }^{c}$ & Ge-free lignite & 0.029 & 1.40 & 65.81 & 0.60 & 4.22 & 12.50 & 9.65 & 3.46 & 97.64 \\
ZZ-68 $^{c}$ & Ge-free lignite & 0.201 & 1.17 & 53.52 & 5.42 & 3.72 & 15.84 & 9.11 & 10.53 & 99.31 \\
\hline
\end{tabular}

Note: ${ }^{\mathrm{a}}$ Ge concentrations were analyzed by ICP-MS; ${ }^{\mathrm{b}}$ The concentrations of hydrogen and oxygen have been calibrated by moisture content; ${ }^{\mathrm{c}} \mathrm{Ge}$-free lignite samples were collected from the second coal-bearing unit $\left(\mathrm{N}_{1 \mathrm{~b}}{ }^{4}\right)$, while Ge-rich lignite samples were collected from the first coal-bearing unit $\left(\mathrm{N}_{1 \mathrm{~b}}{ }^{2}\right)$. 
Table 2 With an exception of organic component, the semiquantitative XRD analysis of mineral content of raw coal samples from the Lincang Ge deposit

\begin{tabular}{lcl}
\hline Sample No. & Ge (ppm) ${ }^{\text {a }}$ & \multicolumn{1}{c}{ Mineral association (\%) } \\
\hline DZ-9 & 1942 & pyrite + quartz + kaolinite + (trace)? \\
DZ-19 & 116 & quartz + kaolinite? \\
DZ-26 & 237 & pyrite (59.5) + kaolinite (13.2) + illite (10.6) + K-feldspar (7.1) + quartz (5.9) + gibbsite (2.7) + gypsum (1.2) + ? \\
DZ-28 & & pyrite (42.6) + quartz (23.2) + kaolinite (12.8) + plagioclase (8.2) + gypsum (4.8) + barite (3.7) \\
ZZ-6 & 385 & quartz (79.3) + calcite (20.7)+? \\
ZZ-10 & 419 & quartz (74.0) + kaolinite (26.0) \\
ZZ-17 & 33.8 & quartz (81.8) + kaolinite (18.2)+? \\
ZZ-21 & 1742 & quartz (41.5) + sanidine (27.7)? + illite (30.8)? \\
ZZ-52 & 2585 & quartz (59.9) + kaolinite (40.1) + ? \\
ZZ-64 ${ }^{\text {b }}$ & 0.422 & pyrite (69.8) + quartz (13.8) + chlorite (7.7) + kaolinite (6.1) + calcite (2.7)? \\
ZZ-68 ${ }^{\text {b }}$ & 0.201 & pyrite (83.7) + quartz (15.0) + gypsum (1.3) + calcite?+? \\
ZZ-72 ${ }^{\text {b }}$ & 0.081 & pyrite (78.0) + quartz (14.5) + kaolinite (4.7) + montmorillonite (2.8) + ? \\
\hline
\end{tabular}

Note: ${ }^{a}$ Ge concentrations were analyzed by ICP-MS; ${ }^{b}$ Ge-free lignite samples were collected from the second coal-bearing unit $\left(\mathrm{N}_{1 b}{ }^{4}\right)$, while Ge-rich lignite samples were collected from the first coal-bearing unit $\left(\mathrm{N}_{1 b}{ }^{2}\right)$. ? stands for unidentified or not sure mineral phases. 
Table 3 Germanium isotopic compositions of various samples from the Lincang Ge Deposit and USGS coal standard sample and Spex Ge standard solution used during HG-MC-ICPMS analysis.

\begin{tabular}{|c|c|c|c|c|c|c|c|c|c|c|c|c|}
\hline Sample No. & Sample type & $\begin{array}{l}\mathrm{Ge}^{\mathrm{a}} \\
(\mathrm{ppm})\end{array}$ & $\begin{array}{c}\text { LOI }^{b} \\
(\%)\end{array}$ & $\begin{array}{c}\text { Ash yield } \\
(\%)\end{array}$ & $\begin{array}{c}\delta^{74} \mathrm{Ge} \\
(\%)\end{array}$ & $2 \sigma$ & $\begin{array}{c}\delta^{73} \mathrm{Ge} \\
(\%)\end{array}$ & $2 \sigma$ & $\begin{array}{c}\delta^{72} \mathrm{Ge} \\
(\% \text { ) }\end{array}$ & $2 \sigma$ & $\begin{array}{c}\delta^{74 / 72} \mathrm{Ge} \\
(\%)\end{array}$ & $2 \sigma$ \\
\hline DZ-1 & sandstone & 1.30 & & & 0.80 & 0.20 & -0.15 & 0.98 & 0.29 & 0.11 & 0.50 & 0.10 \\
\hline ZZ-11 & sandstone & 5.76 & & & 2.64 & 0.09 & 2.05 & 0.11 & 1.36 & 0.05 & 1.28 & 0.05 \\
\hline ZZ-13 & sandstone & 3.48 & & & 1.90 & 0.09 & 1.43 & 0.11 & 0.97 & 0.05 & 0.93 & 0.05 \\
\hline ZZ-14 & sandstone & 8.67 & & & 1.63 & 0.03 & 1.20 & 0.04 & 0.83 & 0.02 & 0.81 & 0.02 \\
\hline \multirow[t]{3}{*}{ ZZ-18 } & sandstone & 1.31 & & & 0.77 & 0.08 & 0.79 & 2.50 & 0.41 & 0.44 & 0.36 & 0.39 \\
\hline & Duplicate & & & & 0.69 & 0.08 & 0.42 & 0.60 & 0.25 & 0.16 & 0.44 & 0.20 \\
\hline & Duplicate & & & & 0.65 & 0.05 & 0.39 & 0.17 & 0.22 & 0.07 & 0.43 & 0.05 \\
\hline \multirow[t]{3}{*}{ LC-3 } & Two-mica granite & 1.69 & & & 0.66 & 0.05 & 0.42 & 0.17 & 0.34 & 0.07 & 0.32 & 0.05 \\
\hline & Duplicate & & & & 0.63 & 0.08 & -0.07 & 2.50 & 0.35 & 0.44 & 0.28 & 0.39 \\
\hline & Duplicate & & & & 0.67 & 0.08 & 0.50 & 0.60 & 0.28 & 0.16 & 0.39 & 0.20 \\
\hline \multirow[t]{3}{*}{ LC-4 } & Two-mica granite & 1.63 & & & 0.70 & 0.08 & 0.31 & 0.60 & 0.36 & 0.16 & 0.34 & 0.20 \\
\hline & Duplicate & & & & 0.69 & 0.08 & 0.09 & 2.50 & 0.33 & 0.44 & 0.36 & 0.39 \\
\hline & Duplicate & & & & 0.71 & 0.05 & 0.49 & 0.17 & 0.38 & 0.07 & 0.33 & 0.05 \\
\hline \multirow[t]{3}{*}{ LC-1 } & Biotite granite & 1.39 & & & 0.60 & 0.05 & 0.47 & 0.17 & 0.31 & 0.07 & 0.29 & 0.05 \\
\hline & Duplicate & & & & 0.57 & 0.08 & -0.84 & 2.50 & 0.35 & 0.44 & 0.22 & 0.39 \\
\hline & Duplicate & & & & 0.63 & 0.08 & 0.25 & 0.60 & 0.33 & 0.16 & 0.30 & 0.20 \\
\hline \multirow[t]{3}{*}{ LC-2 } & Biotite granite & 1.21 & & & 0.59 & 0.08 & 0.52 & 0.60 & 0.27 & 0.16 & 0.32 & 0.20 \\
\hline & Duplicate & & & & 0.42 & 0.08 & -1.48 & 2.50 & 0.14 & 0.44 & 0.28 & 0.39 \\
\hline & Duplicate & & & & 0.59 & 0.05 & 0.64 & 0.17 & 0.35 & 0.07 & 0.24 & 0.05 \\
\hline \multirow[t]{3}{*}{ LC-6 } & Biotite granite & 1.34 & & & 0.55 & 0.08 & 0.39 & 0.60 & 0.27 & 0.16 & 0.28 & 0.20 \\
\hline & Duplicate & & & & 0.48 & 0.08 & -1.95 & 2.50 & 0.24 & 0.44 & 0.24 & 0.39 \\
\hline & Duplicate & & & & 0.59 & 0.05 & 0.45 & 0.17 & 0.23 & 0.07 & 0.36 & 0.05 \\
\hline \multirow[t]{2}{*}{ ZZ-81 } & Chert & 5.55 & 4.06 & & 2.89 & 0.09 & 2.16 & 0.11 & 1.45 & 0.05 & 1.44 & 0.05 \\
\hline & Duplicate & & & & 2.90 & 0.13 & 2.29 & 0.42 & 1.51 & 0.20 & 1.38 & 0.22 \\
\hline \multirow[t]{3}{*}{ ZZ-38 } & Chert & 21.6 & 0.26 & & 0.61 & 0.03 & 0.46 & 0.04 & 0.31 & 0.02 & 0.30 & 0.02 \\
\hline & Duplicate & & & & 0.64 & 0.13 & 0.61 & 0.42 & 0.40 & 0.20 & 0.25 & 0.22 \\
\hline & Duplicate & & & & 0.79 & 0.08 & 0.39 & 0.15 & 0.48 & 0.05 & 0.31 & 0.05 \\
\hline \multirow[t]{3}{*}{ ZZ-45 } & Chert & 25.3 & 1.50 & & 2.15 & 0.03 & 1.62 & 0.04 & 1.11 & 0.02 & 1.05 & 0.02 \\
\hline & Duplicate & & & & 2.16 & 0.13 & 1.70 & 0.42 & 1.11 & 0.20 & 1.04 & 0.22 \\
\hline & Duplicate & & & & 2.24 & 0.08 & 1.48 & 0.15 & 1.20 & 0.05 & 1.05 & 0.05 \\
\hline \multirow[t]{2}{*}{ ZZ-27 } & Chert & 25.3 & 1.50 & & 0.77 & 0.13 & 0.35 & 0.42 & 0.40 & 0.20 & 0.37 & 0.22 \\
\hline & Duplicate & & & & 0.75 & 0.05 & 0.48 & 0.17 & 0.35 & 0.07 & 0.39 & 0.05 \\
\hline \multirow[t]{3}{*}{ ZZ-61 } & Chert & 28.6 & 1.60 & & 0.89 & 0.03 & 0.65 & 0.04 & 0.47 & 0.02 & 0.42 & 0.02 \\
\hline & Duplicate & & & & 0.85 & 0.13 & 0.65 & 0.42 & 0.52 & 0.20 & 0.33 & 0.22 \\
\hline & Duplicate & & & & 0.93 & 0.08 & 0.48 & 0.15 & 0.54 & 0.05 & 0.39 & 0.05 \\
\hline \multirow[t]{3}{*}{ ZZ-87 } & Chert & 33.6 & 6.35 & & 1.29 & 0.03 & 0.97 & 0.04 & 0.67 & 0.02 & 0.62 & 0.02 \\
\hline & Duplicate & & & & 1.25 & 0.13 & 0.99 & 0.42 & 0.69 & 0.20 & 0.55 & 0.22 \\
\hline & Duplicate & & & & 1.28 & 0.08 & 0.75 & 0.15 & 0.70 & 0.05 & 0.57 & 0.05 \\
\hline \multirow[t]{3}{*}{ ZZ-88 } & Chert & 34.9 & & & -0.14 & 0.03 & -0.14 & 0.04 & -0.06 & 0.02 & -0.08 & 0.02 \\
\hline & Duplicate & & & & -0.24 & 0.13 & -0.18 & 0.42 & -0.04 & 0.20 & -0.20 & 0.22 \\
\hline & Duplicate & & & & -0.14 & 0.08 & -0.33 & 0.15 & 0.00 & 0.05 & -0.14 & 0.05 \\
\hline \multirow[t]{3}{*}{ ZZ-84 } & limestone & 40.5 & 2.60 & & 0.55 & 0.03 & 0.38 & 0.04 & 0.26 & 0.02 & 0.29 & 0.02 \\
\hline & Duplicate & & & & 0.49 & 0.13 & 0.36 & 0.42 & 0.26 & 0.20 & 0.23 & 0.22 \\
\hline & Duplicate & & & & 0.55 & 0.08 & 0.18 & 0.15 & 0.36 & 0.05 & 0.20 & 0.05 \\
\hline \multirow[t]{3}{*}{ ZZ-79 } & Chert & 42.6 & 2.10 & & 0.37 & 0.03 & 0.24 & 0.04 & 0.18 & 0.02 & 0.19 & 0.02 \\
\hline & Duplicate & & & & 0.37 & 0.13 & 0.28 & 0.42 & 0.25 & 0.20 & 0.12 & 0.22 \\
\hline & Duplicate & & & & 0.40 & 0.08 & 0.07 & 0.15 & 0.27 & 0.05 & 0.13 & 0.05 \\
\hline
\end{tabular}




\begin{tabular}{|c|c|c|c|c|c|c|c|c|c|c|c|c|}
\hline \multirow[t]{2}{*}{ ZZ-91 } & limestone & 46.1 & 4.05 & & 1.42 & 0.03 & 1.03 & 0.04 & 0.72 & 0.02 & 0.69 & 0.02 \\
\hline & Duplicate & & & & 1.23 & 0.13 & 1.01 & 0.42 & 0.65 & 0.20 & 0.58 & 0.22 \\
\hline \multirow[t]{2}{*}{ ZZ-60 } & limestone & 65.7 & 5.67 & & 0.90 & 0.03 & 0.66 & 0.04 & 0.47 & 0.02 & 0.42 & 0.02 \\
\hline & Duplicate & & & & 0.75 & 0.13 & 0.49 & 0.42 & 0.34 & 0.20 & 0.41 & 0.22 \\
\hline \multirow[t]{2}{*}{ ZZ-77 } & limestone & 87.4 & 14.10 & & 1.82 & 0.03 & 1.34 & 0.04 & 0.94 & 0.02 & 0.88 & 0.02 \\
\hline & Duplicate & & & & 1.74 & 0.13 & 1.39 & 0.42 & 0.93 & 0.20 & 0.81 & 0.22 \\
\hline ZZ-58 & limestone & 93.8 & 9.10 & & 1.87 & 0.03 & 1.37 & 0.04 & 0.95 & 0.02 & 0.91 & 0.02 \\
\hline ZZ-57 & Chert & 167 & 8.70 & & 0.79 & 0.03 & 0.55 & 0.04 & 0.41 & 0.02 & 0.38 & 0.02 \\
\hline ZZ-19 & Chert & 356 & 13.31 & & 1.48 & 0.03 & 1.10 & 0.04 & 0.76 & 0.02 & 0.72 & 0.02 \\
\hline \multirow[t]{2}{*}{ ZZ-50 } & Claystone & 415 & & & 0.18 & 0.08 & 0.07 & 0.10 & 0.09 & 0.06 & 0.09 & 0.04 \\
\hline & Duplicate & & & & 0.22 & 0.10 & 0.13 & 0.06 & 0.11 & 0.03 & 0.11 & 0.09 \\
\hline \multirow[t]{3}{*}{ ZZ-26 } & Ge-rich lignite & 2.64 & & 19.55 & 3.64 & 0.08 & 3.41 & 0.60 & 1.84 & 0.16 & 1.79 & 0.20 \\
\hline & Duplicate & & & & 3.62 & 0.08 & 3.81 & 2.50 & 1.77 & 0.44 & 1.85 & 0.39 \\
\hline & Coal ash & & & & 3.74 & 0.14 & 3.29 & 0.08 & 1.90 & 0.06 & 1.84 & 0.04 \\
\hline \multirow[t]{3}{*}{ ZZ-15 } & Ge-rich lignite & 22.0 & & 40.27 & 2.58 & 0.10 & 1.92 & 0.06 & 1.31 & 0.03 & 1.27 & 0.09 \\
\hline & Duplicate & & & & 2.58 & 0.08 & 1.94 & 0.10 & 1.32 & 0.06 & 1.26 & 0.04 \\
\hline & Coal ash & & & & 3.17 & 0.14 & 2.41 & 0.08 & 1.61 & 0.06 & 1.56 & 0.04 \\
\hline \multirow[t]{2}{*}{ ZZ-16 } & Ge-rich lignite & 27.0 & & 12.40 & 2.75 & 0.10 & 2.08 & 0.06 & 1.40 & 0.03 & 1.34 & 0.09 \\
\hline & Duplicate & & & & 2.70 & 0.08 & 2.03 & 0.10 & 1.40 & 0.06 & 1.29 & 0.04 \\
\hline \multirow[t]{2}{*}{ ZZ-8 } & Ge-rich lignite & 27.1 & & & 2.63 & 0.10 & 2.03 & 0.06 & 1.36 & 0.03 & 1.27 & 0.09 \\
\hline & Duplicate & & & & 2.57 & 0.08 & 1.96 & 0.10 & 1.32 & 0.06 & 1.24 & 0.04 \\
\hline ZZ-17 & Ge-rich lignite & 34.0 & & 16.78 & 1.51 & 0.08 & 1.12 & 0.10 & 0.64 & 0.06 & 0.87 & 0.04 \\
\hline \multirow[t]{3}{*}{ ZZ-9 } & Ge-rich lignite & 48.0 & & 13.22 & 3.96 & 0.08 & 3.00 & 0.15 & 2.03 & 0.05 & 1.92 & 0.05 \\
\hline & Duplicate & & & & 3.88 & 0.08 & 2.93 & 0.09 & 2.00 & 0.06 & 1.88 & 0.05 \\
\hline & Coal ash & & & & 4.15 & 0.14 & 3.16 & 0.08 & 2.14 & 0.06 & 2.00 & 0.04 \\
\hline DZ-4 & Ge-rich lignite & 65.8 & & 5.90 & 3.53 & 0.08 & 2.65 & 0.15 & 1.81 & 0.05 & 1.72 & 0.05 \\
\hline \multirow[t]{2}{*}{ DZ-3 } & Ge-rich lignite & 97.6 & & 12.51 & 2.51 & 0.08 & 1.87 & 0.15 & 1.29 & 0.05 & 1.22 & 0.05 \\
\hline & Duplicate & & & & 2.47 & 0.08 & 1.88 & 0.09 & 1.34 & 0.06 & 1.13 & 0.05 \\
\hline \multirow[t]{3}{*}{ DZ-0 } & Ge-rich lignite & 98.8 & & 13.75 & 2.00 & 0.08 & 1.51 & 0.15 & 1.03 & 0.05 & 0.97 & 0.05 \\
\hline & Duplicate & & & & 2.02 & 0.08 & 1.48 & 0.09 & 1.06 & 0.06 & 0.96 & 0.05 \\
\hline & Coal ash & & & & 2.13 & 0.14 & 1.64 & 0.08 & 1.10 & 0.06 & 1.03 & 0.04 \\
\hline \multirow[t]{2}{*}{ DZ-5 } & Ge-rich lignite & 130 & & 7.25 & 3.55 & 0.08 & 2.67 & 0.09 & 1.83 & 0.06 & 1.72 & 0.05 \\
\hline & Duplicate & & & & 3.56 & 0.08 & 2.68 & 0.15 & 1.84 & 0.05 & 1.71 & 0.05 \\
\hline \multirow[t]{3}{*}{ ZZ-7 } & Ge-rich lignite & 141 & & 14.54 & 1.88 & 0.08 & 1.37 & 0.15 & 0.96 & 0.05 & 0.92 & 0.05 \\
\hline & Duplicate & & & & 1.87 & 0.08 & 1.37 & 0.09 & 0.97 & 0.06 & 0.90 & 0.05 \\
\hline & Coal ash & & & & 1.80 & 0.14 & 1.34 & 0.08 & 0.91 & 0.06 & 0.89 & 0.04 \\
\hline \multirow[t]{2}{*}{ DZ-2 } & Ge-rich lignite & 186 & & 23.55 & 1.75 & 0.08 & 1.25 & 0.15 & 0.89 & 0.05 & 0.86 & 0.05 \\
\hline & Duplicate & & & & 1.74 & 0.08 & 1.26 & 0.09 & 0.89 & 0.06 & 0.85 & 0.05 \\
\hline \multirow[t]{2}{*}{ DZ-26 } & Ge-rich lignite & 237 & & 19.87 & 1.69 & 0.08 & 1.27 & 0.15 & 0.87 & 0.05 & 0.82 & 0.05 \\
\hline & Duplicate & & & & 1.70 & 0.08 & 1.25 & 0.09 & 0.88 & 0.06 & 0.82 & 0.05 \\
\hline \multirow[t]{2}{*}{ ZZ-12 } & Ge-rich lignite & 240 & & 4.39 & 4.72 & 0.08 & 3.53 & 0.09 & 2.41 & 0.06 & 2.30 & 0.05 \\
\hline & Duplicate & & & & 4.69 & 0.08 & 3.51 & 0.15 & 2.42 & 0.05 & 2.26 & 0.05 \\
\hline \multirow[t]{3}{*}{ DZ-24 } & Ge-rich lignite & 256 & & 10.09 & 0.49 & 0.08 & 0.31 & 0.09 & 0.27 & 0.06 & 0.22 & 0.05 \\
\hline & Duplicate & & & & 0.50 & 0.08 & 0.36 & 0.15 & 0.30 & 0.05 & 0.21 & 0.05 \\
\hline & Coal ash & & & & 0.47 & 0.14 & 0.32 & 0.08 & 0.24 & 0.06 & 0.23 & 0.04 \\
\hline ZZ-103 & Ge-rich lignite & 317 & & & 1.90 & 0.08 & 1.34 & 0.10 & 0.99 & 0.06 & 0.91 & 0.04 \\
\hline ZZ-104 & Ge-rich lignite & 334 & & & 2.32 & 0.08 & 1.71 & 0.10 & 1.18 & 0.06 & 1.13 & 0.04 \\
\hline ZZ-6 & Ge-rich lignite & 385 & & 12.27 & 1.92 & 0.08 & 1.50 & 0.15 & 1.00 & 0.05 & 0.92 & 0.05 \\
\hline & Duplicate & & & & 1.88 & 0.08 & 1.38 & 0.09 & 0.98 & 0.06 & 0.90 & 0.05 \\
\hline ZZ-34 & Ge-rich lignite & 402 & & 8.31 & 1.60 & 0.08 & 1.13 & 0.09 & 0.84 & 0.06 & 0.76 & 0.05 \\
\hline & Coal ash & & & & 1.49 & 0.14 & 1.09 & 0.08 & 0.77 & 0.06 & 0.72 & 0.04 \\
\hline ZZ-10 & Ge-rich lignite & 419 & & 15.13 & 2.69 & 0.08 & 1.94 & 0.09 & 1.41 & 0.06 & 1.28 & 0.05 \\
\hline
\end{tabular}




\begin{tabular}{|c|c|c|c|c|c|c|c|c|c|c|c|}
\hline & Duplicate & & & 2.79 & 0.08 & 1.89 & 0.15 & 1.47 & 0.05 & 1.31 & 0.05 \\
\hline \multirow[t]{3}{*}{ DZ-6 } & Ge-rich lignite & 835 & 9.85 & 0.79 & 0.08 & 0.47 & 0.09 & 0.42 & 0.06 & 0.36 & 0.05 \\
\hline & Duplicate & & & 0.84 & 0.08 & 0.42 & 0.15 & 0.51 & 0.05 & 0.33 & 0.05 \\
\hline & Coal ash & & & 0.86 & 0.14 & 0.61 & 0.08 & 0.44 & 0.06 & 0.43 & 0.04 \\
\hline DZ-8 & Ge-rich lignite & 975 & 11.20 & 0.54 & 0.08 & 0.19 & 0.15 & 0.33 & 0.05 & 0.21 & 0.05 \\
\hline ZZ-25 & Ge-rich lignite & 1105 & 7.33 & 3.81 & 0.08 & 2.65 & 0.15 & 2.01 & 0.05 & 1.80 & 0.05 \\
\hline DZ-7 & Ge-rich lignite & 1127 & 10.35 & 0.23 & 0.08 & -0.03 & 0.15 & 0.18 & 0.05 & 0.05 & 0.05 \\
\hline DZ-18 & Ge-rich lignite & 1233 & 16.33 & -0.39 & 0.08 & -0.51 & 0.15 & -0.15 & 0.05 & -0.25 & 0.05 \\
\hline \multirow[t]{3}{*}{ DZ-15 } & Ge-rich lignite & 1352 & 15.93 & -0.74 & 0.08 & -0.46 & 0.10 & -0.37 & 0.06 & -0.36 & 0.04 \\
\hline & Duplicate & & & -0.61 & 0.08 & -0.55 & 0.10 & -0.31 & 0.06 & -0.30 & 0.04 \\
\hline & Coal ash & & & -0.43 & 0.14 & -0.39 & 0.08 & -0.23 & 0.06 & -0.20 & 0.04 \\
\hline \multirow[t]{3}{*}{ ZZ-53 } & Ge-rich lignite & 1363 & 13.99 & -2.59 & 0.08 & -2.01 & 0.10 & -1.32 & 0.06 & -1.27 & 0.04 \\
\hline & Duplicate & & & -2.54 & 0.10 & -2.00 & 0.06 & -1.35 & 0.03 & -1.19 & 0.09 \\
\hline & Duplicate & & & -2.81 & 0.08 & -2.05 & 0.10 & -1.42 & 0.06 & -1.39 & 0.04 \\
\hline \multirow[t]{2}{*}{ ZZ-46 } & Ge-rich lignite & 1382 & 4.77 & 0.68 & 0.08 & 0.50 & 0.10 & 0.36 & 0.06 & 0.32 & 0.04 \\
\hline & Duplicate & & & 0.66 & 0.10 & 0.44 & 0.06 & 0.35 & 0.03 & 0.31 & 0.09 \\
\hline \multirow[t]{2}{*}{ DZ-13 } & Ge-rich lignite & 1395 & 10.27 & 0.44 & 0.08 & 0.33 & 0.10 & 0.22 & 0.06 & 0.22 & 0.04 \\
\hline & Duplicate & & & 0.42 & 0.10 & 0.27 & 0.06 & 0.23 & 0.03 & 0.19 & 0.09 \\
\hline \multirow[t]{2}{*}{ DZ-14 } & Ge-rich lignite & 1531 & 14.77 & -0.18 & 0.08 & -0.17 & 0.10 & -0.09 & 0.06 & -0.09 & 0.04 \\
\hline & Duplicate & & & -0.20 & 0.10 & -0.20 & 0.06 & -0.09 & 0.03 & -0.11 & 0.09 \\
\hline \multirow[t]{2}{*}{ DZ-12 } & Ge-rich lignite & 1535 & 13.23 & -0.13 & 0.10 & -0.16 & 0.06 & -0.06 & 0.03 & -0.07 & 0.09 \\
\hline & Duplicate & & & -0.13 & 0.08 & -0.19 & 0.10 & -0.08 & 0.06 & -0.05 & 0.04 \\
\hline ZZ-21 & Ge-rich lignite & 1742 & 2.81 & 1.59 & 0.14 & 1.17 & 0.08 & 0.82 & 0.06 & 0.78 & 0.04 \\
\hline \multirow[t]{3}{*}{ DZ-9 } & Ge-rich lignite & 1942 & 6.94 & -0.42 & 0.10 & -0.36 & 0.06 & -0.20 & 0.03 & -0.22 & 0.09 \\
\hline & Duplicate & & & -0.42 & 0.08 & -0.37 & 0.10 & -0.22 & 0.06 & -0.20 & 0.04 \\
\hline & Coal ash & & & -0.31 & 0.14 & -0.28 & 0.08 & -0.17 & 0.06 & -0.14 & 0.04 \\
\hline ZZ-51 & Ge-rich lignite & 2020 & 9.73 & 1.19 & 0.08 & 0.87 & 0.10 & 0.61 & 0.06 & 0.57 & 0.04 \\
\hline ZZ-22 & Ge-rich lignite & 2234 & 6.77 & 0.79 & 0.14 & 0.55 & 0.08 & 0.41 & 0.06 & 0.38 & 0.04 \\
\hline ZZ-49 & Ge-rich lignite & 2319 & 12.19 & 0.75 & 0.08 & 0.53 & 0.10 & 0.39 & 0.06 & 0.37 & 0.04 \\
\hline ZZ-48 & Ge-rich lignite & 2431 & 10.05 & 0.49 & 0.08 & 0.31 & 0.10 & 0.27 & 0.06 & 0.22 & 0.04 \\
\hline \multirow[t]{3}{*}{ ZZ-52 } & Ge-rich lignite & 2585 & 5.77 & 0.98 & 0.08 & 0.69 & 0.10 & 0.52 & 0.06 & 0.46 & 0.04 \\
\hline & Duplicate & & & 0.86 & 0.08 & 0.60 & 0.10 & 0.50 & 0.06 & 0.36 & 0.04 \\
\hline & Coal ash & & & 1.26 & 0.14 & 0.90 & 0.08 & 0.66 & 0.06 & 0.60 & 0.04 \\
\hline ZZ-1\# & soot & 21974 & & 1.52 & 0.08 & 1.14 & 0.10 & 0.81 & 0.06 & 0.71 & 0.04 \\
\hline ZZ-2\# & soot & 11107 & & 1.25 & 0.08 & 0.92 & 0.10 & 0.69 & 0.06 & 0.56 & 0.04 \\
\hline \multirow[t]{2}{*}{ ZZ-3\# } & cinder & 23.0 & & 2.69 & 0.08 & 1.95 & 0.10 & 1.24 & 0.06 & 1.45 & 0.04 \\
\hline & Duplicate & & & 2.79 & 0.08 & 2.03 & 0.10 & 1.25 & 0.06 & 1.54 & 0.04 \\
\hline ZZ-4\# & cinder & 10.1 & & 3.50 & 0.08 & 2.60 & 0.10 & 1.75 & 0.06 & 1.74 & 0.04 \\
\hline CLB-1 & USGS coal & & & 1.22 & 0.08 & 1.08 & 0.15 & 0.63 & 0.05 & 0.59 & 0.05 \\
\hline CLB-1 & USGS coal & & & 1.44 & 0.09 & 1.22 & 0.11 & 0.72 & 0.05 & 0.72 & 0.05 \\
\hline \multirow[t]{2}{*}{ CLB-1 } & USGS coal & & & 1.24 & 0.08 & 1.06 & 0.15 & 0.62 & 0.05 & 0.61 & 0.05 \\
\hline & Duplicate & & & 1.18 & 0.08 & 1.04 & 0.09 & 0.60 & 0.06 & 0.57 & 0.05 \\
\hline \multirow[t]{2}{*}{ CLB-1 } & USGS coal & & & 1.17 & 0.10 & 1.03 & 0.06 & 0.59 & 0.03 & 0.58 & 0.09 \\
\hline & Duplicate & & & 1.20 & 0.08 & 1.05 & 0.10 & 0.62 & 0.06 & 0.58 & 0.04 \\
\hline \multirow[t]{2}{*}{ Ge-Spex* } & Standard solution & & & -0.66 & 0.13 & -0.39 & 0.42 & -0.37 & 0.20 & -0.29 & 0.22 \\
\hline & Duplicate & & & -0.68 & 0.09 & -0.51 & 0.11 & -0.37 & 0.05 & -0.32 & 0.05 \\
\hline \multirow[t]{2}{*}{ Ge-Spex* } & Standard solution & & & -0.70 & 0.13 & -0.39 & 0.42 & -0.37 & 0.20 & -0.33 & 0.22 \\
\hline & Duplicate & & & -0.79 & 0.03 & -0.61 & 0.04 & -0.41 & 0.02 & -0.38 & 0.02 \\
\hline \multirow[t]{2}{*}{ Ge-Spex* } & Standard solution & & & -0.80 & 0.08 & -0.58 & 0.15 & -0.42 & 0.05 & -0.38 & 0.05 \\
\hline & Duplicate & & & -0.72 & 0.08 & -0.50 & 0.09 & -0.37 & 0.06 & -0.35 & 0.05 \\
\hline Ge-Spex* & Standard solution & & & -0.66 & 0.10 & -0.51 & 0.06 & -0.35 & 0.03 & -0.31 & 0.09 \\
\hline
\end{tabular}




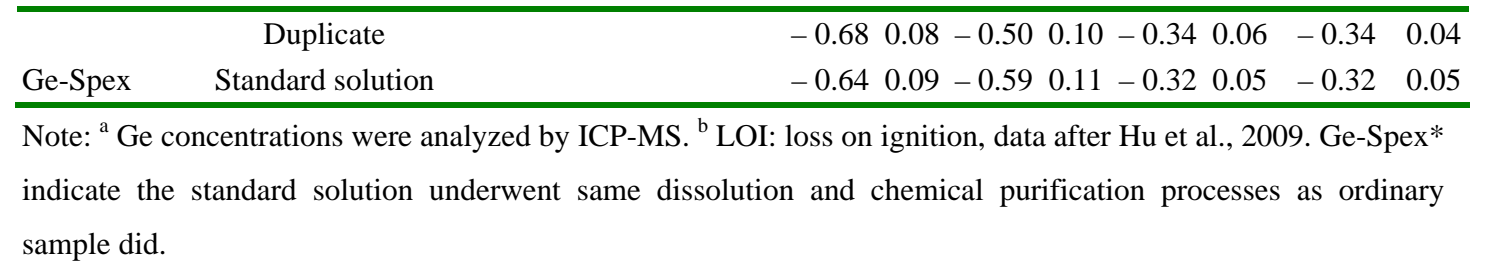

Table 4 The analyzed random vitrinite reflectance and Ge concentrations of lignite samples from the Lincang Ge deposit

\begin{tabular}{|c|c|c|c|c|c|c|}
\hline Sample No. & Ge (ppm) & Spots analyzed & $R_{\min }(\%)$ & $R_{\max }(\%)$ & $R_{\text {mean }}(\%)$ & $T_{\max }{ }^{\mathrm{a}}\left({ }^{\circ} \mathrm{C}\right)$ \\
\hline DZ-0 & 98.8 & 31 & 0.46 & 0.56 & 0.52 & 70.0 \\
\hline DZ-2 & 186 & 41 & 0.50 & 0.66 & 0.59 & 86.2 \\
\hline DZ-3 & 97.6 & 42 & 0.42 & 0.55 & 0.49 & 62.4 \\
\hline DZ-4 & 65.8 & 42 & 0.34 & 0.50 & 0.41 & 39.5 \\
\hline DZ-5 & 130 & 41 & 0.41 & 0.49 & 0.45 & 51.5 \\
\hline DZ-6 & 835 & 42 & 0.39 & 0.52 & 0.44 & 48.6 \\
\hline DZ-7 & 1127 & 42 & 0.42 & 0.55 & 0.47 & 57.0 \\
\hline DZ-8 & 975 & 42 & 0.43 & 0.53 & 0.49 & 62.4 \\
\hline DZ-18 & 1233 & 41 & 0.34 & 0.42 & 0.39 & 33.1 \\
\hline DZ-21 & & 41 & 0.44 & 0.60 & 0.51 & 67.5 \\
\hline DZ-26 & 237 & 45 & 0.36 & 0.47 & 0.43 & 45.6 \\
\hline ZZ-6 & 385 & 40 & 0.44 & 0.49 & 0.46 & 54.3 \\
\hline ZZ-7 & 141 & 40 & 0.55 & 0.67 & 0.60 & 88.4 \\
\hline ZZ-9 & 48.0 & 45 & 0.41 & 0.52 & 0.47 & 57.0 \\
\hline ZZ-10 & 419 & 41 & 0.54 & 0.62 & 0.59 & 86.2 \\
\hline ZZ-12 & 240 & 41 & 0.40 & 0.50 & 0.46 & 54.3 \\
\hline ZZ-15 & 22.0 & 43 & 0.45 & 0.57 & 0.49 & 62.4 \\
\hline ZZ-16 & 27.0 & 42 & 0.47 & 0.60 & 0.53 & 72.5 \\
\hline ZZ-17 & 34.0 & 42 & 0.41 & 0.55 & 0.47 & 57.0 \\
\hline ZZ-21 & 1742 & 41 & 0.42 & 0.55 & 0.46 & 54.3 \\
\hline ZZ-22 & 2234 & 44 & 0.52 & 0.62 & 0.56 & 79.5 \\
\hline ZZ-46 & 1382 & 42 & 0.45 & 0.57 & 0.50 & 65.0 \\
\hline ZZ-48 & 2431 & 44 & 0.40 & 0.52 & 0.44 & 48.6 \\
\hline ZZ-49 & 2319 & 42 & 0.45 & 0.55 & 0.49 & 62.4 \\
\hline ZZ-51 & 2020 & 41 & 0.33 & 0.43 & 0.39 & 33.1 \\
\hline ZZ-53 & 1363 & 41 & 0.37 & 0.47 & 0.43 & 45.6 \\
\hline ZZ-55 & & 31 & 0.48 & 0.61 & 0.54 & 74.8 \\
\hline ZZ-64 ${ }^{\mathrm{b}}$ & 0.422 & 40 & 0.36 & 0.45 & 0.4 & 36.4 \\
\hline
\end{tabular}




\begin{tabular}{lllllll}
\hline ZZ-66 $^{\mathrm{b}}$ & 0.029 & 41 & 0.4 & 0.49 & 0.46 & 54.3 \\
ZZ-68 $^{\mathrm{b}}$ & 0.201 & 41 & 0.4 & 0.48 & 0.44 & 48.6 \\
ZZ-72 $^{\mathrm{b}}$ & 0.081 & 40 & 0.41 & 0.49 & 0.45 & 51.5 \\
\hline
\end{tabular}

Note: ${ }^{\text {a }} T_{\max }$ values were calculated using the equation $\operatorname{Ln}\left(R_{\text {mean }}\right)=0.0078 T_{\max }-1.2$ (Barker and Pawlewicz, 1986); ${ }^{\mathrm{b}}$ Ge-free lignite samples were collected from the second coal-bearing unit $\left(\mathrm{N}_{1 \mathrm{~b}}{ }^{4}\right)$, while Ge-rich lignite samples were collected from the first coal-bearing unit $\left(\mathrm{N}_{1 \mathrm{~b}}{ }^{2}\right)$.

Table 5 Melting and boiling point of various elements and their concentration in soot and cinder samples from the Lincang Ge deposit (ppm).

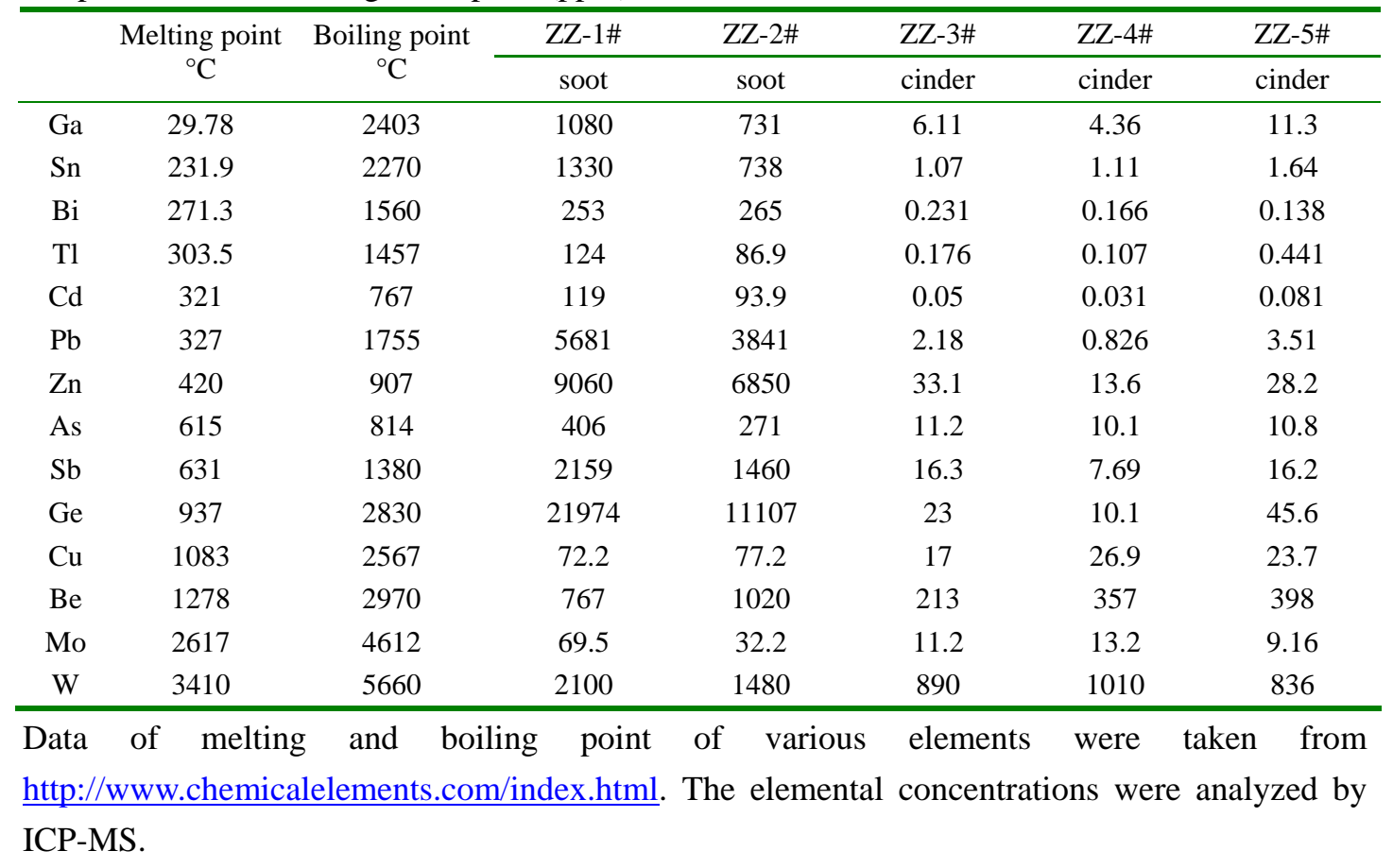




\section{Figure Number and Figure Captions}

Fig. 1 Simplified regional geological map of the Bamgmai Basin, Yunnan, Southwest China (modified after Hu et al., 2009).

Fig. 2 Geological cross-sections of the Lincang Ge deposit (after Li, 2000; Qi et al., 2004).

Fig. 3 Summary of Ge isotopic composition of various samples from the Lincang Ge deposit, as well as other Earth and planetary materials in literatures. The vertical bar represents the estimated Ge isotopic composition $\left(\delta^{74} \mathrm{Ge}=0.59 \pm 0.18 \%\right.$ o) of Bulk Silicate Earth (BSE) (Escoube et al., submitted for publication). Data sources: ${ }^{a}$ this study, ${ }^{\mathrm{b}}$ Luais (2007), ${ }^{\mathrm{c}}$ Rouxel et al. (2008), and ${ }^{\mathrm{d}}$ Rouxel et al. (2006).

Fig. 4 Scatter diagram of Ge concentration vs. Ge isotopic composition of Ge-rich lignites from the Lincang Ge deposit. A negative correlation can be found between Ge concentrations and $\delta^{74} \mathrm{Ge}$ values. For Ge-rich lignite samples from the Dazhai ore block, $\delta^{74} \mathrm{Ge}=-0.0018$ [Ge]+2.45, $\mathrm{r}=0.85, \mathrm{n}=16$; while for these samples from the Zhongzhai ore block, with an exception of one sample (ZZ-53), $\quad \delta^{74} \mathrm{Ge}=-0.0008[\mathrm{Ge}]+2.85, \mathrm{r}=0.67, \mathrm{n}=21$.

Fig. 5 Vertical variations of Ge concentration and Ge isotope composition in profiles of coal seams from the Lincang Ge deposit. Horizontal dashed lines represent lithologic boundaries. In coal seams, Ge is mainly concentrated in the top or the bottom, while high values of $\delta^{74} \mathrm{Ge}$ occur in the middle. The vertical bar represents the estimated Ge isotopic composition $\left(\delta^{74} \mathrm{Ge}=0.59 \pm 0.18 \%\right.$ of of Bulk Silicate Earth (BSE) (Escoube et al., submitted for publication).

Fig. 6 Scatter diagram of Ge concentration vs. Ge isotopic composition and loss on ignition (LOI) of Ge-rich chert and limestone samples from the Lincang Ge deposit. LOI Data from Hu et al. (2009).

Fig. 7 Scatter diagram of Ge isotopic compositions of raw coal and corresponding coal ashes 
of Ge-rich lignite samples from the Lincang Ge deposit.

Fig. 8 Scatter diagram of Ge concentration vs. Ge isotopic composition of soot and cinder samples from the Lincang Ge deposit.

Fig. 9 Germanium isotopic fractionations produced by Rayleigh fractionation processes during sorption of Ge in coal and precipitation of quartz, as a function of the proportion of Ge removed. An initial solution Ge isotopic composition of $\delta^{74} \mathrm{Ge}_{\mathrm{i}}=1.7 \%$ was selected, and equilibrium fractionation factors $\left(\alpha_{\mathrm{Coal}-\mathrm{Ge}(\mathrm{OH}) 4}\right.$ and $\left.\alpha_{\text {quartz-Ge(OH)4 }}\right)$ were calculated at $\mathrm{T}=50{ }^{\circ} \mathrm{C}$ from formula in $\mathrm{Li}$ et al. (2009). $\alpha_{\mathrm{Coal}-\mathrm{Ge}(\mathrm{OH}) 4}$ is approximated by $\alpha_{\mathrm{Ge}-\text { catechol-Ge(OH)4. }}$

Fig. 10 Schematic model based on Rayleigh fractionation used to explain the relationship between Ge concentration and Ge isotope composition along the migratory direction of a vertical Ge plume that represents ascending hydrothermal solution penetrating a coal seam. An initial solution Ge isotopic composition of $1.7 \%$ and initial solution Ge concentration of 30ppb for solution was chosen, and $\alpha_{\text {Coal-Ge(OH)4 }}=0.99557$. 


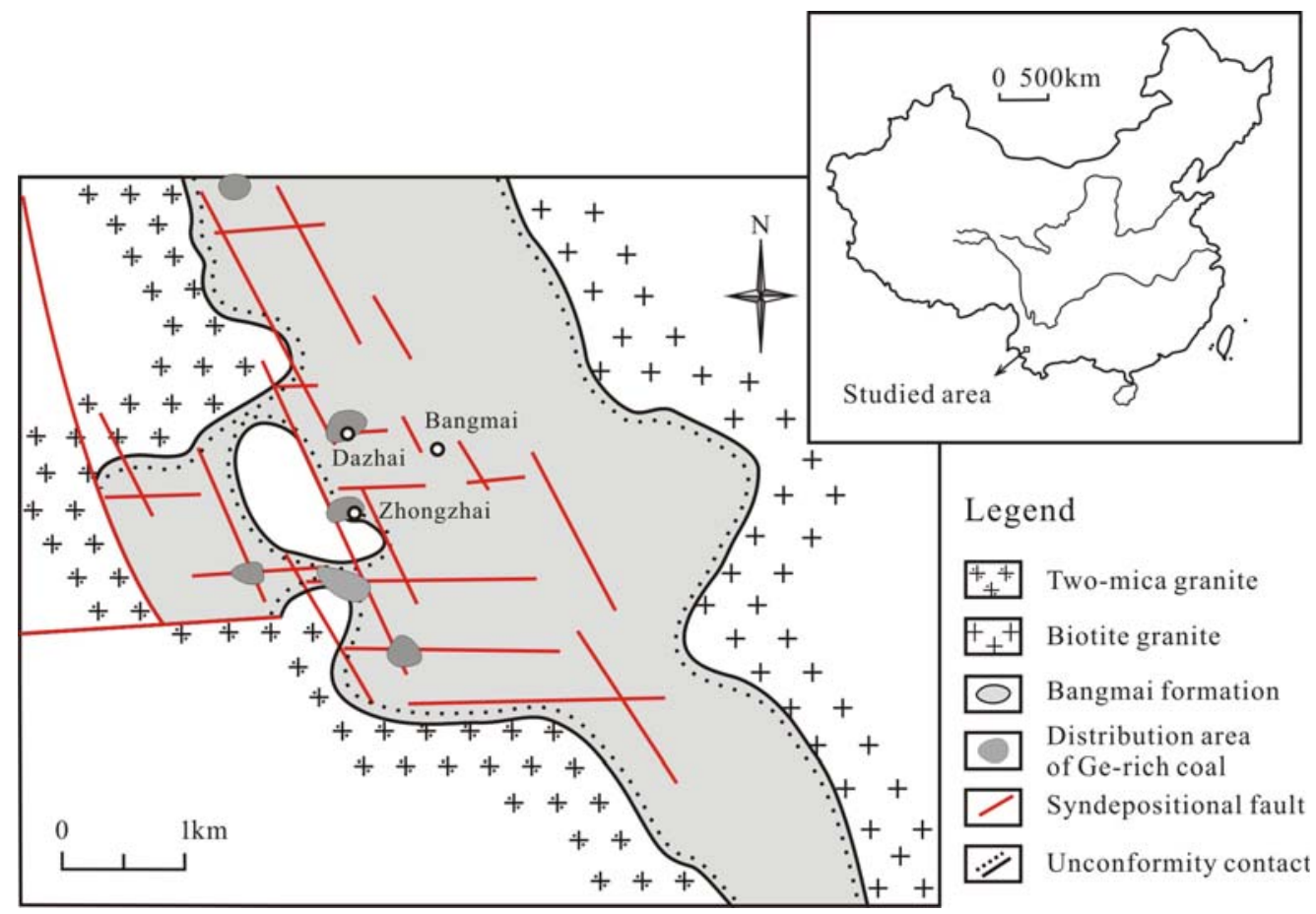

Fig. 1

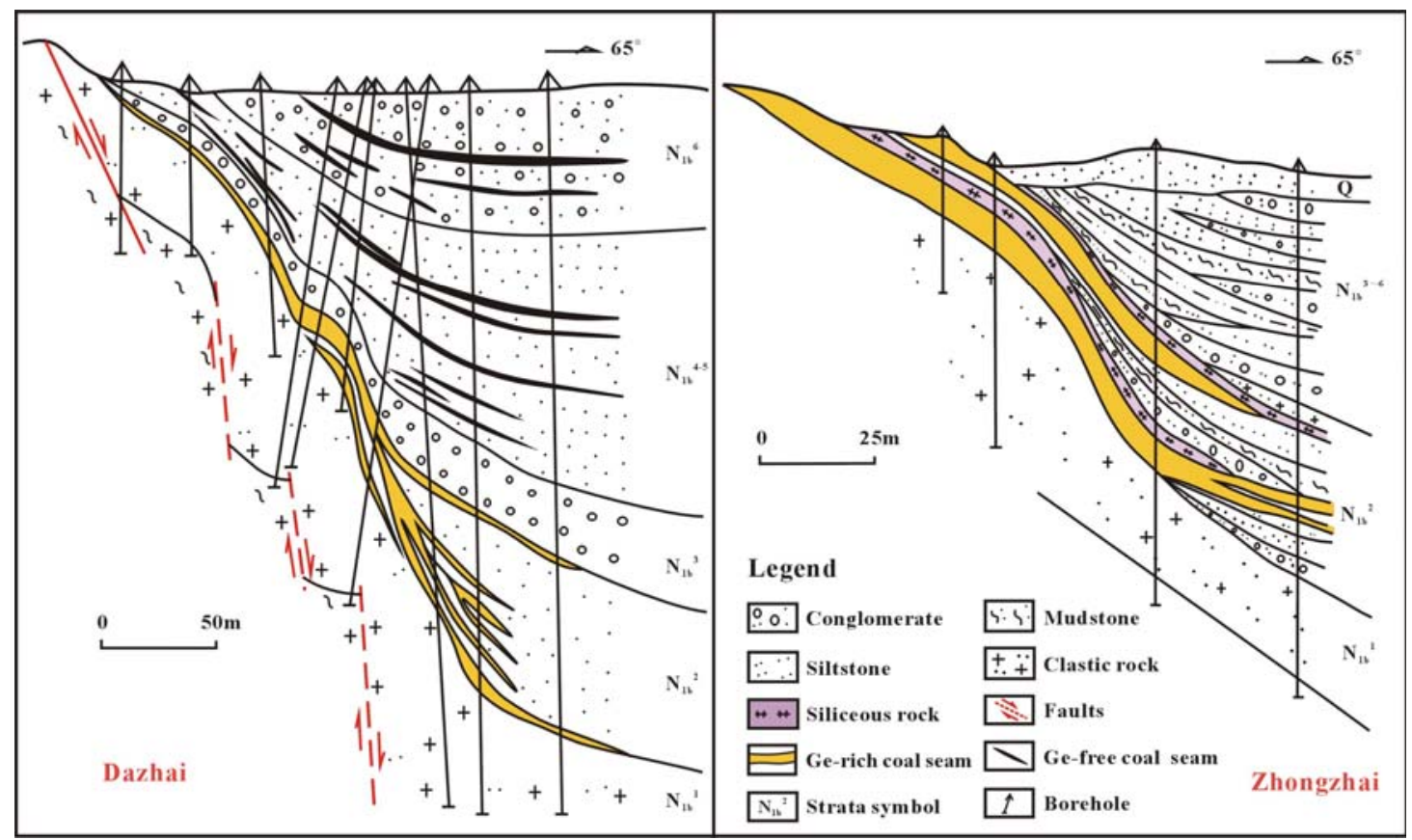

Fig. 2 


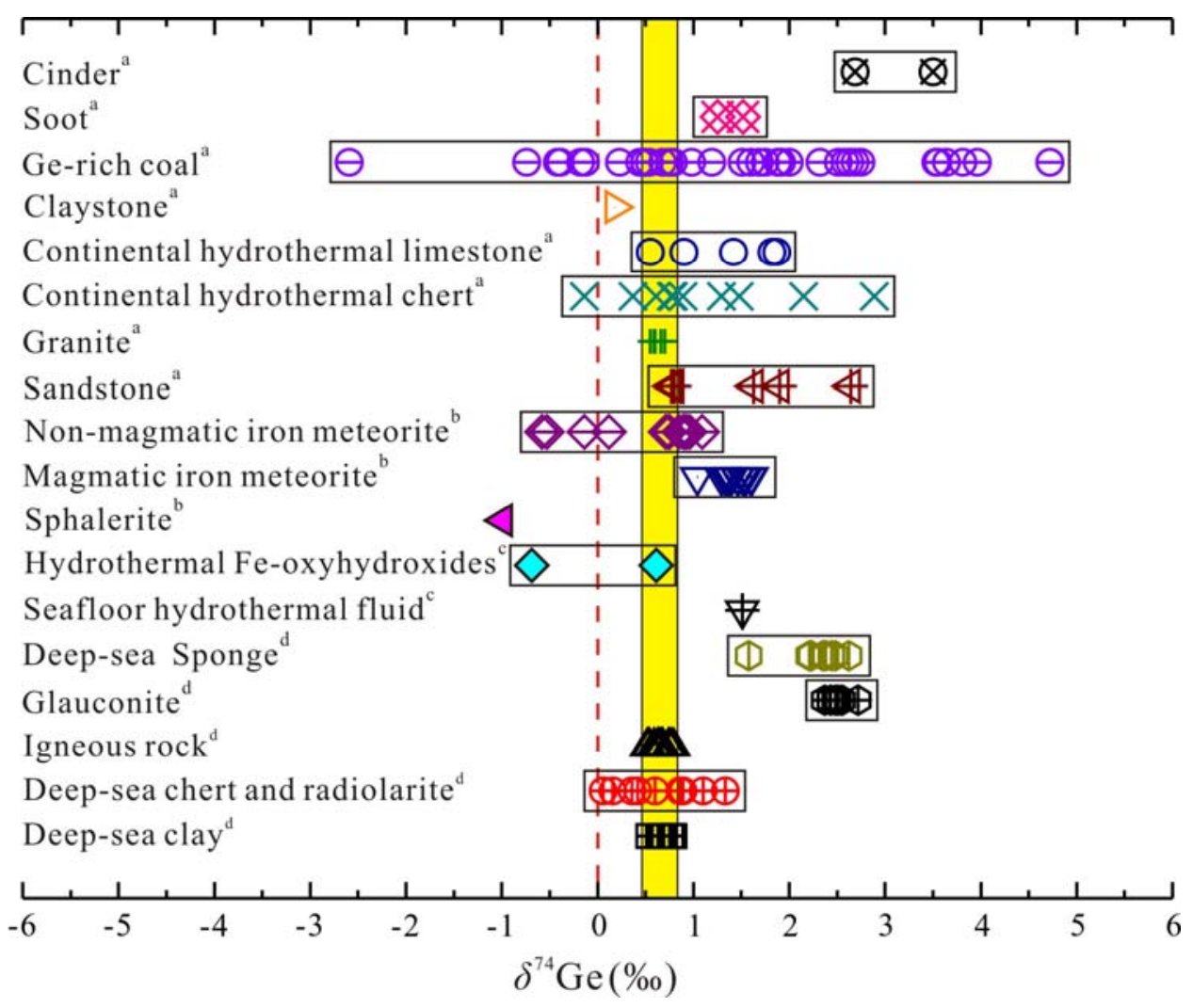

Fig. 3

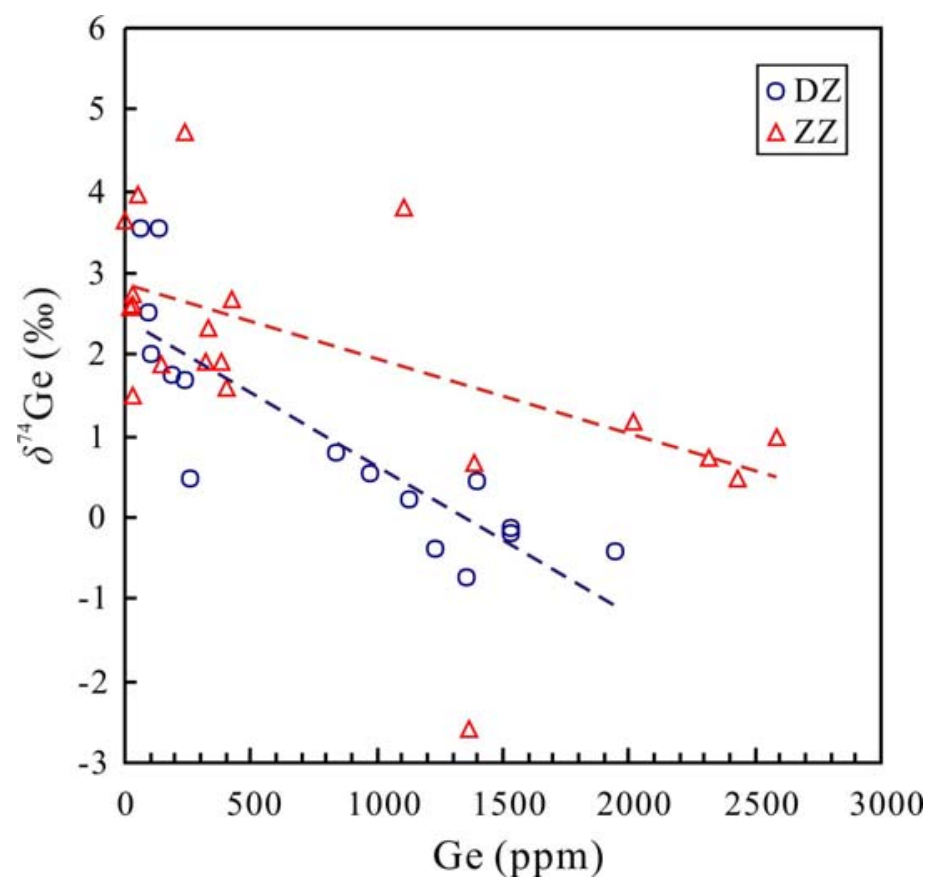

Fig. 4 

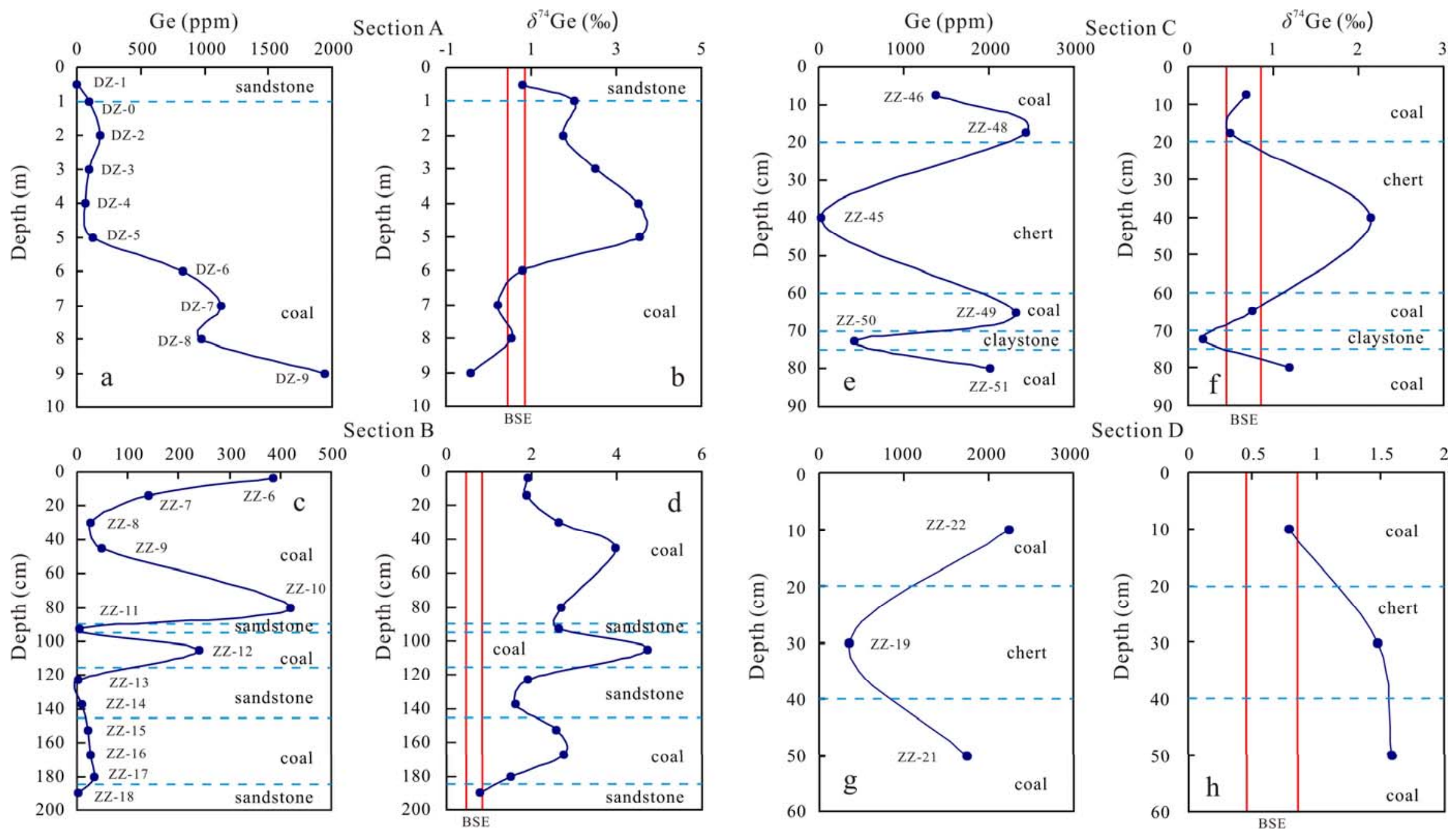

Fig. 5 


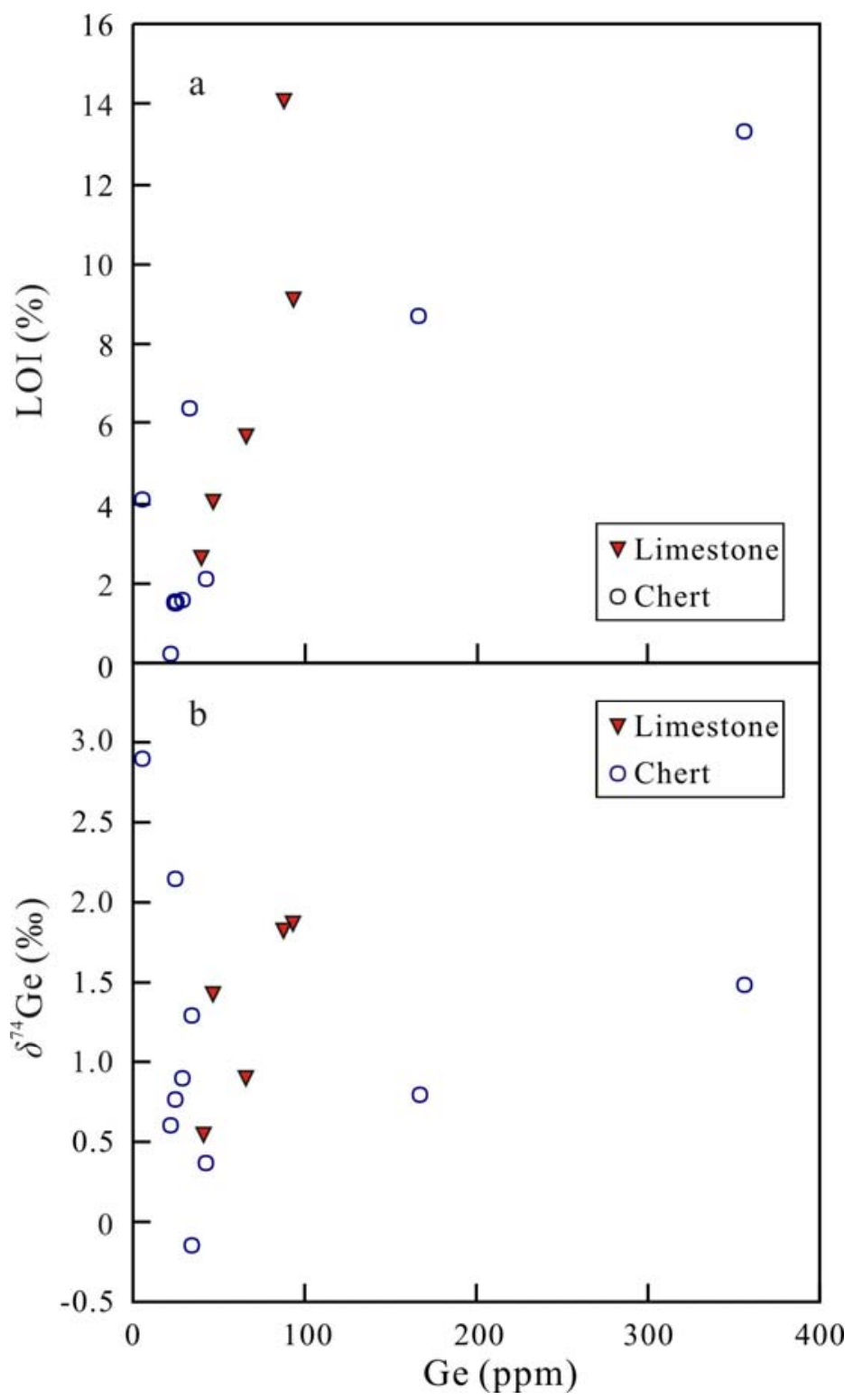

Fig. 6 


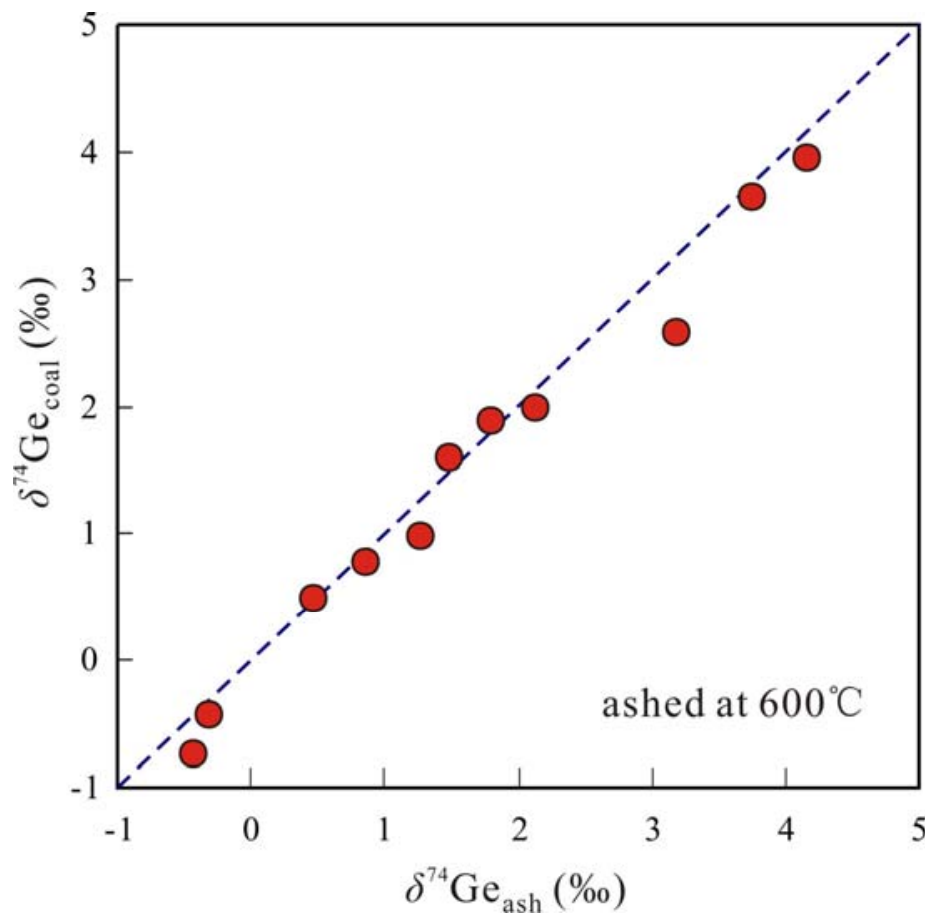

Fig. 7

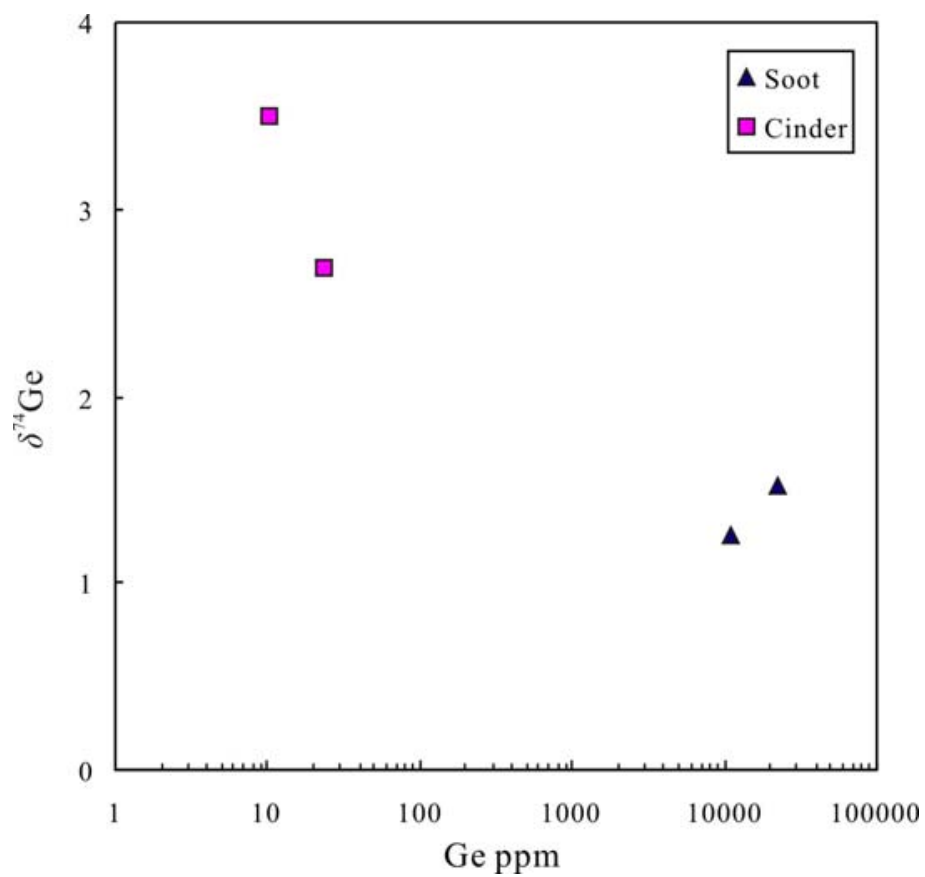

Fig. 8 


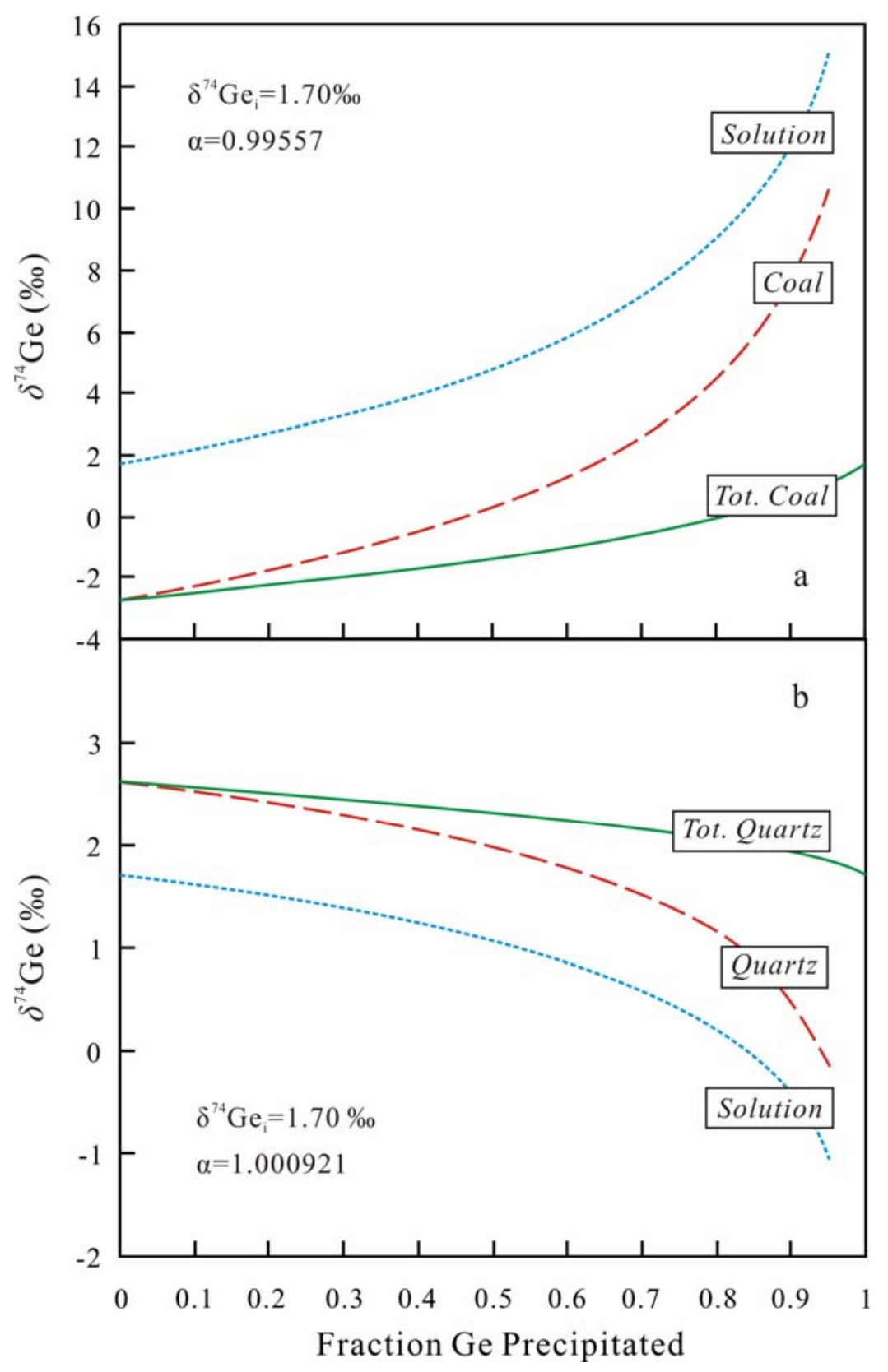

Fig. 9 


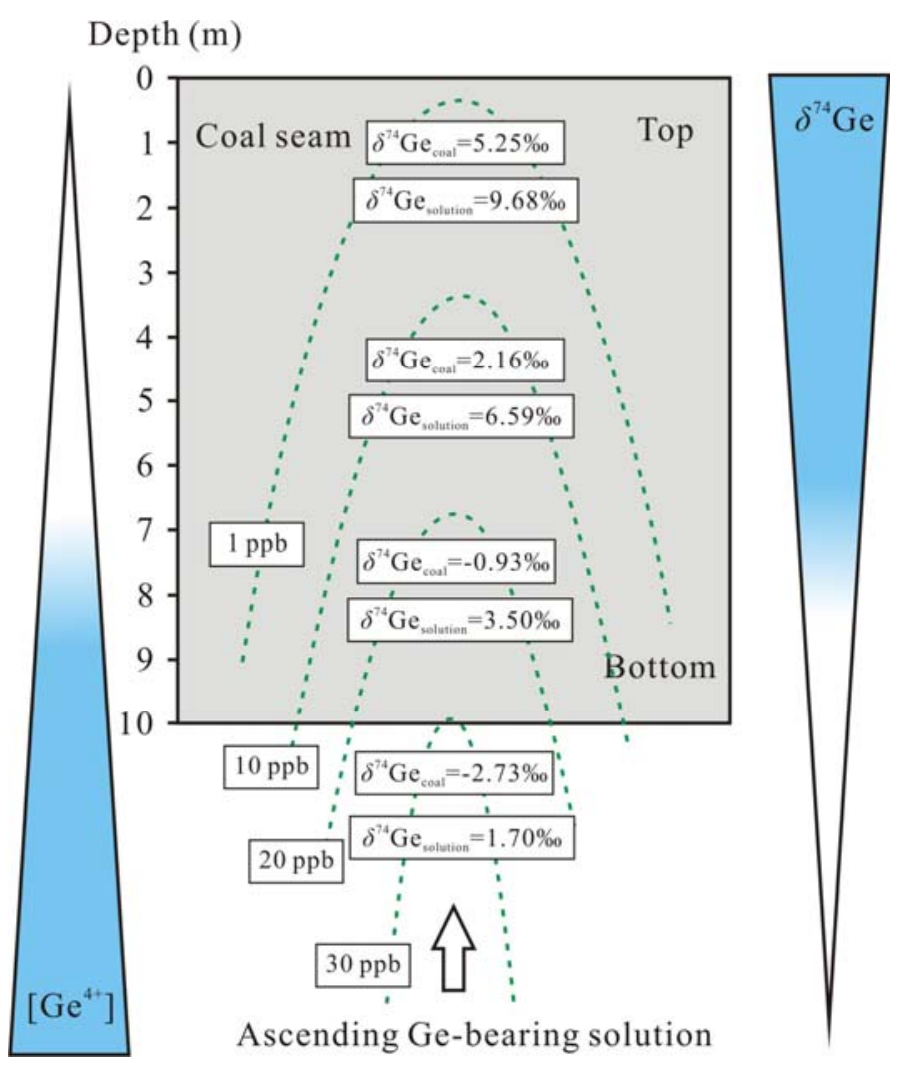

Fig. 10 